\title{
A literature review of occurrence of Egyptian Vulture (Neophron percnopterus) resident in Africa
}

\author{
Volen Arkumarev $^{1 *}$, Mike McGrady ${ }^{2}$ and Ivaylo Angelov ${ }^{3}$ \\ ${ }^{1}$ Bulgarian Society for Protection of Birds / BirdLife Bulgaria, Yavorov complex, bl. 71, en. 4, PO box 50, 1111 Sofia, Bulgaria \\ ${ }^{2}$ International Avian Research, Am Rosenhügel 59, 3500 Krems, Austria. \\ ${ }^{3}$ Gorno Pole 6480, Madzharovo, Bulgaria \\ *Corresponding author: Volen Arkumarev email: volen.arkumarev@gmail.com
}

http://dx.doi.org/10.4314/vulnew.v77i1.1

\begin{abstract}
The Egyptian Vulture Neophron percnopterus is a globally endangered species that is experiencing rapid population declines throughout most of its range. Conservation of Egyptian Vultures in Africa is globally important because it holds a resident population of $1000-2000$ breeding pairs, harbours a significant but unknown number of Eurasian migrants during the boreal winter, and many non-adult Egyptian Vultures reared in Eurasia dwell in Africa until they mature. Africa comprises approximately half of the area of the global range of the species. Once considered common and widespread in many parts of Africa, Egyptian Vulture is now one of the vulture species that is most threatened with extinction. Egyptian Vulture is considered extinct as a breeding species in Southern Africa, and continuous population declines have been reported from most of its African range, resulting in a population reduction of perhaps $75 \%$. Despite these declines, there is an apparent lack of systematic observations, and its current status in many African countries is unknown. Furthermore, little is known about the magnitude of the various threats and their impact on resident and wintering Egyptian Vultures. Data-deficiency hinders conservation efforts across the continent. We conducted an extensive review of published and unpublished information on the resident Egyptian Vulture populations in Africa, in an attempt to systemize the available knowledge of the species' historic and current occurrence on a country-by country basis and identify the threats it faces. Information was found from 39 countries; no records of Egyptian Vultures were found in 16 other countries. In 12 countries where Egyptian Vultures have been observed, breeding has never been confirmed, and observations most likely refer to vagrants or wintering individuals. The Horn of Africa appears to be a relative stronghold, but there too, losses almost certainly have occurred. Poisoning, electrocution and direct killing for belief-based practices are considered the main mortality factors, and are hampering the species' recovery. The review highlights the dire status of Egyptian Vultures in Africa, and calls for the urgent implementation of various large-scale conservation measures that will combat threats, secure the survival of the species on the continent, and make Africa safer for migrants coming from Eurasia.
\end{abstract}




\section{Introduction}

The Egyptian Vulture (Neophron percnopterus) is a small scavenger distributed throughout the Palaearctic, Afrotropical and western Indohimalayan geographic regions (Ferguson-Lees et al. 2001). The nominate subspecies, N.p. percnopterus, occurs in southern Europe, the Middle East, Africa, south-west and central Asia, east to the Tien Shan and Pakistan. N. p. majorensis is endemic to the Canary Islands, limited to the eastern islands of Lanzarote, Fuerteventura and Alegranza. The smaller Asian subspecies, N.p. ginginianus, is largely sedentary, and restricted to the Indian sub-continent (Pakistan, India, Nepal) (Iñigo et al. 2008). In 2007 the species was up listed from "Least Concern" to "Endangered" in the IUCN Red List, becoming the first vulture species occurring in Africa listed as such. The global population is estimated at $18000-57000$ individuals (12000 - 38000 mature individuals) with $3000-4700$ breeding pairs in Europe, 1000 pairs in the Middle East, $<2000$ pairs in Central Asia, a few thousand pairs in the Indian subcontinent, and about $1000-2000$ breeding pairs in Africa (BirdLife International 2018a). Rapid population declines have been recorded in most of its range. In India, it has declined by more than $90 \%$ in the last ten years (Cuthbert et al. 2006); European populations have declined by $50-79 \%$ over the last three generations (BirdLife International 2018a), and populations in Africa have declined significantly (Jennings 2010, Ogada et al. 2016). In Arabia the situation may be mixed; Jennings (2010) reports declines, but the population in Oman appears to be growing (Angelov et al. 2013, Meyburg et al. in press)

The African range of Egyptian Vulture is huge, concentrated along a broad band of the Sahel from Sudan (Nikolaus 1987), Ethiopia, Somalia, Eritrea and Djibouti in the east, to Senegal in the west (Rondeau and Thiollay 2004, Petersen et al. 2007,
Wacher et al. 2013), and south to Kenya and northern Tanzania. It also occurs in North Africa (Morocco, Tunisia, Algeria, Libya and Egypt, Levy 1996). A small sedentary population occurred in South Africa and possibly Angola and Namibia (Mundy et al. 1992), but it is now considered extinct as a breeder there (Taylor et al. 2015).

Egyptian Vultures breeding in the mountain massifs of the Sahara, the Sahel and further south, and in Afromontane regions are considered sedentary; sedentary populations occur also on the Canary Islands (Donázar et al. 2002b) and Socotra (Porter \& Suleiman 2012). African populations breeding north of the Sahara are migratory (Kemp 1998, Thiollay 1989, Borrow \& Demey 2014). The wintering grounds of vultures from breeding grounds in Europe and western Asia largely overlap with the range of the resident populations in West and East Africa and the Sahelian countries (Cramp \& Simmons 1980, Meyburg et al. 2004, Buechley \& Şekercioğlu 2013, Oppel et al. 2015). What is thought to be a majority of juveniles of the migratory populations dwell in southern areas, including Africa, for some years, returning to northern breeding areas only as they approach sexual maturity (Yosef \& Alon 1997, Oppel et al. 2015).

Many publications point to and document the decline of the Egyptian Vulture across Africa (e.g. Ogada et al. 2016, Virani et al. 2011, Rondeau and Thiollay 2004), but comprehensive studies are lacking. The absence of such studies stimulated this continent-wide review, the aim of which is to provide comprehensive information on the status and occurrence of the Egyptian Vulture on a country-by country basis, and detail the main threats it faces in Africa. The review identifies sources of information and provides important historical context for considering the current state of the populations, addressing the threats, and 
drawing comparisons between the African and global populations. So as to animate the information in this document, we also propose conservation measures that might address or mitigate the main threats to the species in Africa. This review can serve as a stepping stone for planning future studies on Egyptian Vultures, and launching successful conservation programmes across its African range.

\section{Methods}

We conducted an extensive review of published and unpublished information on Egyptian Vulture populations in Africa. The review sought information from all countries of mainland Africa and the islands that belong to it geographically. Countries were grouped geographically following Ogada \& Buij (2011), making it easier to consider regional conditions and deal with information that came from border areas between countries. The absence of a national account in this review indicates that we were unable to find any information on Egyptian Vultures for that country. Within the country accounts we have divided the data into two time periods: "Historical data" are those collected before 2000, and "Recent data" are from 2000 to 2018.

Information came from scientific and natural history journals, books, theses, bird atlases, popular publications, records held in the African Raptor Databank. Initially we assembled data from standard texts and internet sites that provided summary and sometimes national data (e.g. Cramp \& Simmons 1980, Brown et al. 1997, del Hoyo et al. 1994, BirdLife International 2018a, Botha et al. 2017). To locate other relevant publications, we searched the Web of Science (http://apps.webofknowledge.com/) and Google Scholar (https://scholar.google.com/), using keywords including country names, 'Egyptian Vulture' (in English, French, German and Italian) and 'Neophron percnopterus'. We examined the references listed in those publications for sources of information that had not been found in other ways. Initial drafts of national accounts were then sent out to experts and others with possible direct knowledge of the past and current status of Egyptian Vultures in those countries, and their comments were used to improve the accounts. We also sought to fill gaps in information by contacting sources via social media and email. Despite our best efforts, we cannot claim to have found every relevant publication, and for various reasons (such as suspected unreliability of data) some of those found are not cited in this paper. Our primary focus is on resident birds and populations. We include extensive, albeit less comprehensive, information about migrant birds.

\section{Results}

\section{North Africa}

The Egyptian Vulture population in North Africa has decreased dramatically over the last century; considered a common and widespread species in the past, its population has shrunk considerably. Egyptian Vulture was classified as extinct by some authors in Tunisia and Libya, but recent observations have confirmed that it still breeds there. Algeria and Egypt probably hold the largest populations in the region. The strongholds are in Northern Algeria (Oum El Bouaghi, Djurdjura National Park and Belezma National Park) and Southern Egypt (Red Sea mountains and Nile Valley;

https://northafricanbirds.wordpress.com/2015/10/1 9/egyptian-vulture-algeria/). In Morocco the species was considered to be on the verge of extinction, but recent observations of breeding pairs and a communal roosting site in the Middle Atlas Mountains give hope for the vulture's persistence (Fig. 1) 


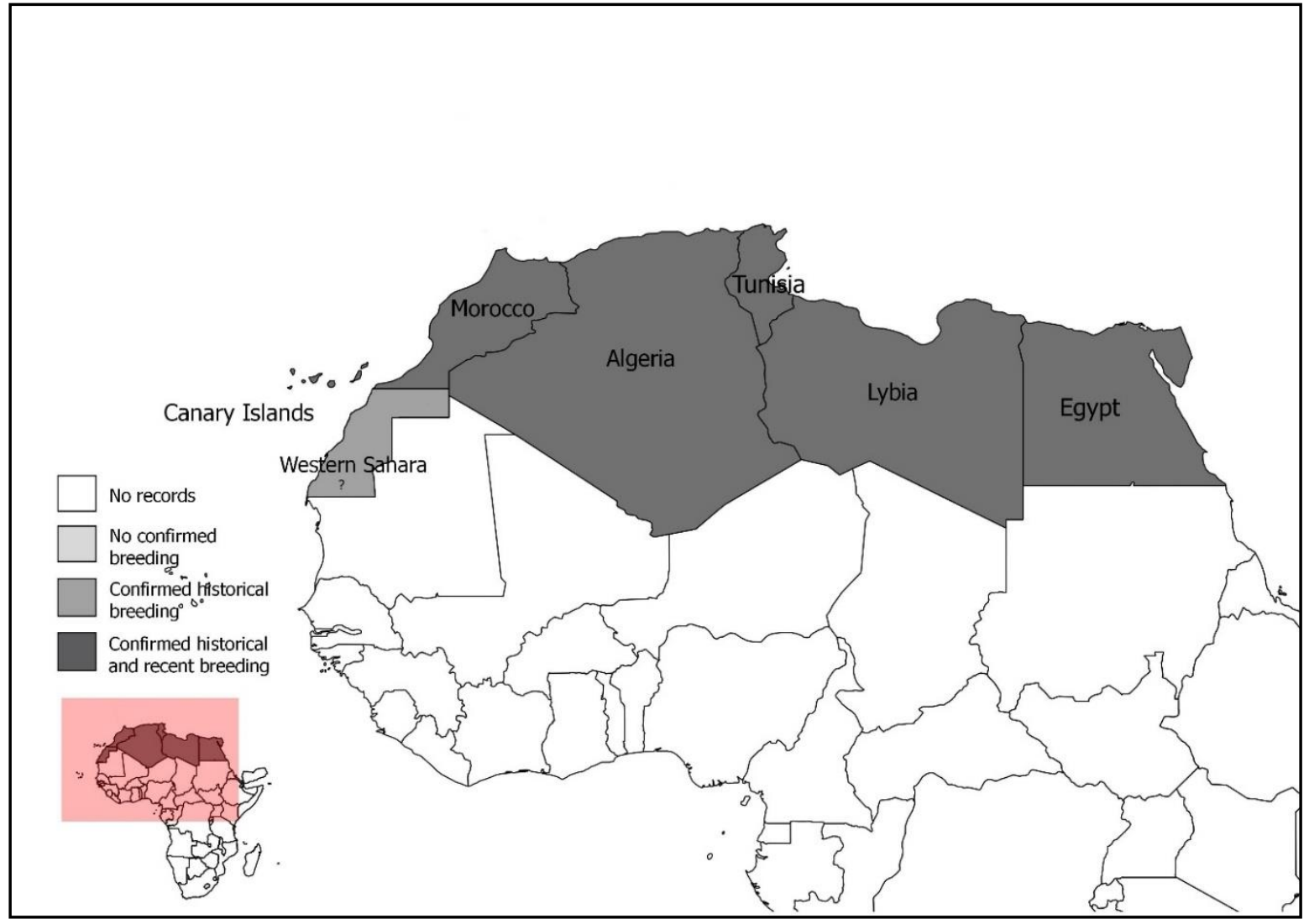

Figure 1: Map of the Egyptian Vulture occurrence in North Africa. (? = recent or historical records of possible, but unconfirmed breeding).

\section{Algeria}

\section{Historical data}

The first observations of the Egyptian Vulture in Algeria were reported in 1858 (Loche \& Bonaparte 1858). In the beginning of the $20^{\text {th }}$ century, Jourdain (1915) recorded it as common near Tebessa, and occasionally seen at Ain Mokra; breeding pairs were spotted at El Kantara, and in the mountains to the south. It was also recorded on cliffs near Hammam Meskoutine; scattered pairs were nesting on the hills near Ain Djenedeli, and several pairs were observed in the gorge of the Rummel at Konstantine. It was considered especially common in Kabylie, where an incomplete census in 1989 in Greater Kabylie found 32 nests (Moali \& Gaci 1992). It was also especially common in the
Ouarsenis Massif, but uncommon in the west (Oran, Sidi-Bel-Abbès, though seen around Saïda, Mascara and Tlemcen) (Isenmann \& Maoli 2000). In the south, a small, probably sedentary, population occurred in the Ahaggar (breeding records come from further north in the Mouydir Gorge), and probably in the Tassili n'Ajjer (Isenmann \& Maoli 2000). Levy (1996) estimated 30-50 breeding pairs, but subsequently those numbers were considered an underestimation (Isenmann \& Maoli 2000). Ledant et al. (1981) reviewed the status of the species in the country, and state: "breeding extends from the coast southward to the Saharan Atlas and beyond (Béni Ounif, Béchar and perhaps Tindouf)". 


\section{Recent data}

According to recent information, "Algeria still has populations of Griffon Vultures, but other species have disappeared due to poisoning" (Hancock 2010). However, Thiollay \& Mostefai (2004) recorded a pair of Egyptian Vultures in the area of Tlemcen, northwestern-most Algeria. Single adults were observed in eastern Ahaggar in March of 2005 (Wacher et al. 2005). Egyptian Vultures of various ages have been observed at rubbish dumps in M'Sila Province, and some observers indicate that the species is still present in good numbers in the regions of Djurdjura National Park and Belezma National Park (S. Messabhia in litt.). Messabhia et al. (2018) present the results of the first detailed study of Egyptian Vulture breeding ecology in Algeria, studying a breeding group in Oum El Bouaghi. The species returns from wintering areas in the second week of March, and starts incubation in April. Clutch size, breeding success, nest location and exposition were measured for seven active nests. The mean nearest neighbour distance was extremely low: $50.6 \mathrm{~m}$. All pairs were breeding within $5 \mathrm{~km}$ of a rubbish dump, which was used as a primary food resource (Messabhia et al. 2018).

\section{Egypt}

\section{Historical data}

Heuglin (1869) mentioned Egyptian Vultures breeding on the pyramids, and Gurney (1876) also found them to be common in Cairo, and cited Hasselquist (1751) who mentioned thousands of Egyptian Vultures feeding on dead asses (Equus africanus asinus) and camels (Camelus dromedarius) around Cairo. According to Jourdain (1935), in the 1930s the species was already reduced to small numbers. Meinertzhagen (1930) also noticed a decrease in numbers, especially in more agricultural areas, and its local disappearance from the Cairo region. Mullié \& Meininger (1985) judged that the decrease in Egypt started more than a century earlier. Goodman et al. (1989) states that it probably bred in small numbers in the Nile Valley, south of Luxor, particularly in the Lake Nasser area, and in the mountainous areas of the Eastern Desert, where it was observed throughout the year. In Sinai, single pairs with fledglings were recorded near St. Katherine and Ain Musa in the beginning of the 1980s (Goodman et al. 1989).

\section{Recent data}

Recent breeding in Egypt has been recorded in Sinai and the Red Sea mountains (S. Baha el Din, in litt.). In 2006, an adult and juvenile were recorded in Wadi Arbaein, Sinai, individuals at Ain Hodra and Wadi Itlah, and a single Egyptian Vulture was observed flying over the cliffs in Ain Hodra in July 2007 (White et al. 2008). Two possible pairs were recorded during 8 days in April 2010 in the mountains near Bir Shalateen, though they were considered to be uncommon breeders in the area (M. Clouet in litt.). Baha el Din (2010) notes that the species sporadically breeds from Gebel Elba to Wadi el-Gemal National Park, but records from the park may be questionable. However, there are frequent observations from near Sheikh el-Shazeli. The species is commonly seen at waste dumps and camel carcasses near the town of Shalateen (Baha el Din 2010). In 2012, M. Baha el Din noted, 'there have been marked declines of resident populations of Egyptian Vulture and the south-eastern desert is the last known stronghold' (in litt.). The population in Egypt was estimated at 10-100 pairs (Meyburg \& Meyburg 1987), though recent reports suggest there are currently fewer (M. Baha el Din in litt.).

\section{Libya}

\section{Historical data}

Guichard (1955), who studied the birds of the large province of Fezzan and south Tripolitania, mentioned the Egyptian Vulture as being 
"uncommon in western Libya between the coast and Jebel Soda (Nafusa Mountains), and in the Fezzan was seen only once near Aramas". The species presumably bred in Jebel Al Akhdar in Cyrenaica (Bundy 1976). Cramp \& Simmons (1980) cited Toschi (1969) and mentioned that the species had "declined markedly in Cyrenaica in the last 25 years", and the decline continued afterwards (Levy 1996). Mundy (2000) states, 'What little news there is from Libya is alarming.' A report from J. Svehlik in the mid-1980s stated that 'everything that moves is shot at' (Meyburg \& Meyburg 1987), and in a 30-month period he saw no vultures. According to information from the mid-1990s, there were two nesting areas in the country: near the Tunisian border (Nalul-JaushJado), and in the Jebel Al Akhdar hills (F. Liberatori, pers. comm., Levy 1996).

\section{Recent data}

Recent information states that "the vultures have disappeared from the country" (Hancock 2010), but in 2010 a pair of Egyptian Vultures was observed during the breeding season in Cyrenaica, and quite probably some breeding pairs exist, but in very low numbers (R. Tovey, pers. comm.).

\section{Morocco}

\section{Historical data}

In the early 1980s, it was estimated that $500-1000$ pairs of Egyptian Vultures were breeding in Morocco (Thevenot et al. 1985). The species was considered to be "widespread throughout Morocco, but at much lower density than the abundance of food would permit, especially from traditional stock farming" (Thevenot et al. 1985). However, this estimation has to be treated with caution as data were not gathered using large-scale surveys (Amezian \& El Khamlichi 2016). Later, Mundy et al. (1992) mentioned that although Egyptian Vultures were widespread, they were less numerous than expected.

\section{Recent data}

Garrido et al. (2005) did not mention any observation of Egyptian Vultures in northern Morocco during a Griffon Vulture survey. Based on old records, the species was considered on the verge of extinction by some authors (El Agbani \& Qninba 2011). However, a recent study in the Middle Atlas Mountains found two occupied breeding territories with chicks, and a communal roosting site with 40 individuals of various ages (Amezian \& El Khamlichi 2016). A study by these same authors in 2016 estimated the breeding population in the Middle Atlas (same areas as in 2014) to number 20 - 30 breeding pairs (Amezian \& El Khamlichi, unpublished data). Among the main threats are poisoning and the use of vulture parts in 'traditional medicine'. In the Middle Atlas Mountains, poisoning is considered rare in areas where the main human activity is small livestock farming because they use sheep dogs to guard the flocks. However, in the forested areas, such as those near Tazekka National Park, poison is still used, albeit probably more rarely than in the past because wolf abundance has declined (Amezian \& El Khamlichi 2016). Direct persecution was also important in the past, but it is less important now (M. Amezian in litt.).

\section{Tunisia}

\section{Historical data}

Whitaker (1905) described the Egyptian Vulture as "common throughout the greater part of the regency", and mentioned a breeding locality in Jebel Resas (about $20 \mathrm{~km}$ southeast of Tunis). He also stated that "further south the species may be met with more or less sparingly wherever mountains occur". The Egyptian Vulture could be found on all major rock faces of the Dorsale Mountains, the Teboursouk Mountains and some 
rocky outcrops in the north - Jebel Ichkeul, Jebel Mnaguisse and Jebel Sria. It was rarely found in the wooded hills of Kroumirie and the Mogood Hills. Jebel el Haouaria was the only site in Cape Bon where it occurred, and it was rare in the Matmata Mountains and the regions of Sidi Bouzid, Gafsa and Degache (Isenmann et al. 2005). A partial census in 1975 found 75 pairs (Cramp \& Simmons, 1980), but Meyburg \& Meyburg (1987) have estimated the population to number at least 200 breeding pairs. During the period 1975 - 1990, the nesting population seemed stable and was estimated to number around $100-150$ pairs ( $\mathrm{T}$. Gaultier, see Levy 1996). Tunisian Egyptian Vultures spend the winter in tropical Africa (Lavauden 1924, Heim de Balsac \& Mayaud 1962, Etchecopar \& Hüe 1964, Isenmann et al. 2005).

\section{Recent data}

Preliminary results of research of old nests and newly occupied sites since 2001, revealed that tens of old nesting sites had been abandoned, some new sites were occupied, and a decrease of about $44 \%$ in the total number of breeders in comparison to the last estimation made in the 90's (Tunisian Wildlife Conservation Society (TWCS) unpublished data). The national estimate is currently about $60-80$ pairs, the majority of which are nesting in the Dorsale Mountains (Ridha Ouni in litt.). The Egyptian Vulture breeds in loose colonies in Jebel Zaghouan, Jebel Orbata, Jebel Metlaoui et Chbika. In other areas single breeding pairs exist (Ridha Ouni in litt.).

\section{Western Sahara}

\section{Historical data}

Valverde (1957) reports sightings of Egyptian Vultures from three areas ans confirmed breeding during the first half of the $20^{\text {th }}$ century.

\section{Recent data}

We could find no evidence of recent records of Egyptian Vultures in Western Sahara

\section{$\underline{\text { West Africa }}$}

Egyptian Vulture has not been confirmed as a breeder in a number of West African countries (Burkina Faso, Gambia, Guinea, Senegal and Togo), although in those countries single observations of individuals exist (Fig. 2). Severe population declines have been recorded in areas once considered as strongholds in Mali, Nigeria and on the Cape Verde Islands. According to the latest estimations only $7-11$ breeding pairs persist on the Cape Verde archipelago. Egyptian Vulture is most probably extinct from Air Massif, but still breeds in the Termit Massif and Koutous in Niger, and also in Hombri-Dounza Massif in Mali. However, no reliable population estimates for those areas exist. The species has recovered from a severe population decline only on the Canary Islands, where the population currently exceeds 300 individuals, including 60 breeding pairs.

\section{Burkina Faso}

No historical records were found of Egyptian Vultures breeding in Burkina Faso, but GPS tracked individuals from Italy and Spain have been recorded visiting the country during the boreal winter (Ceccolini et al. 2009, VCF unpublished data). However, during a recent vulture survey no Egyptian Vultures were recorded (Rondeau \& Thiollay 2004). 


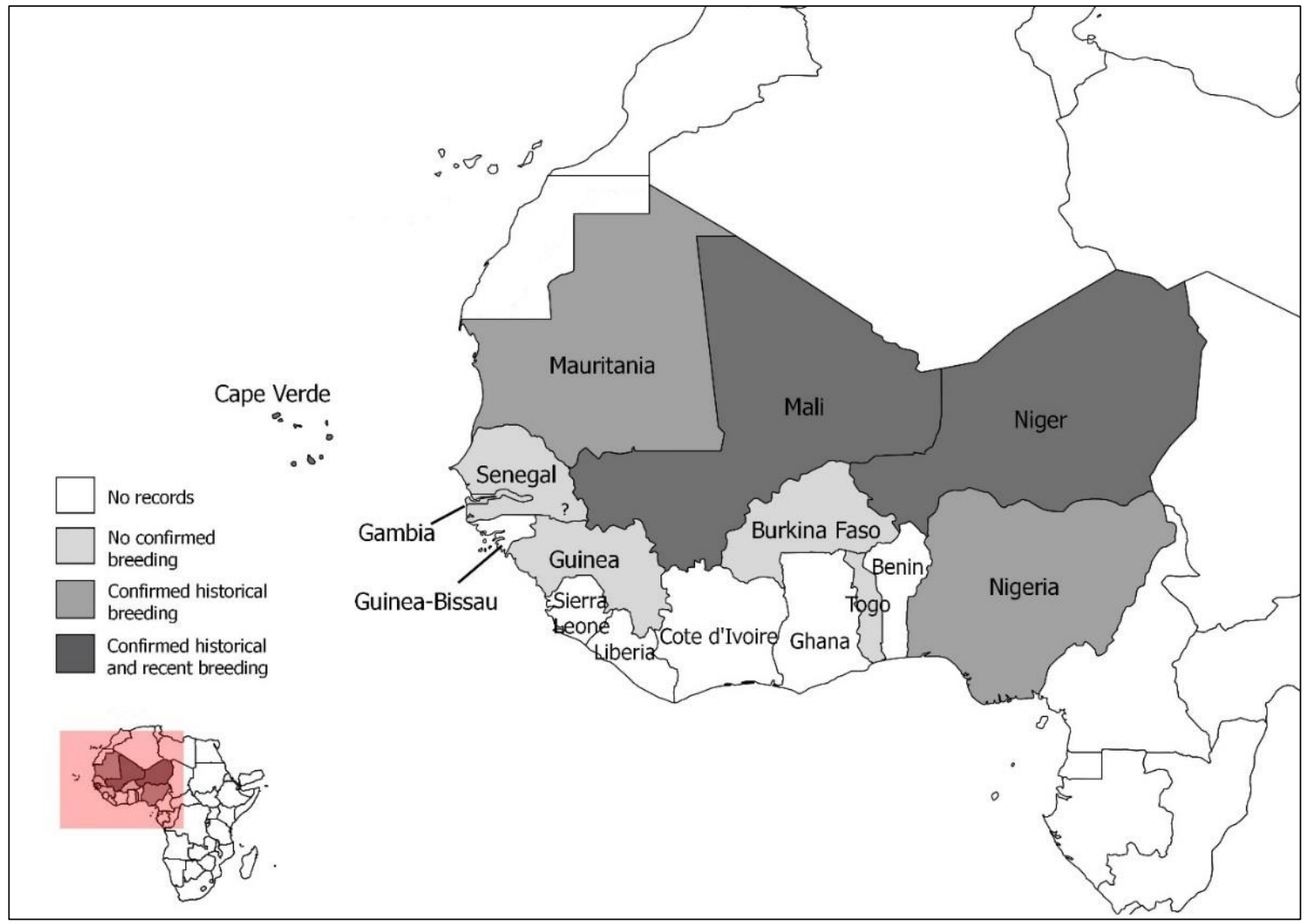

Fig. 2. Map of the Egyptian Vulture occurrence in West Africa (? = recent or historical records of possible, but unconfirmed breeding).

\section{Canary Islands, Spain}

\section{Historical data}

The population on the Canary Islands is nonmigratory, and isolation, albeit incomplete (Agudo et al. 2011), has led to subspecies designation: N. p. majorensis (Kretzmann et al. 2003, Donázar 2002b). The first census of the Egyptian Vulture on the Canary Islands was undertaken in 1987. The population was estimated at 31-37 pairs, mainly breeding on Fuerteventura (26-31 pairs), with the rest breeding on Lanzarote (Delgado et al. 1993). Egyptian Vulture was reported as being frequently observed until the middle of the $20^{\text {th }}$ century on the island of Tenerife (Lack \& Southern 1949, Volsoe 1951). Since then, a decline has been evident, and according to Martin (1987) the population on Tenerife in 1984 comprised at least three individuals ( 1 adult and 2 subadults), restricted to the Teno Massif. However, during the census in 1987 no Egyptian Vultures were recorded on Tenerife (Delgado et al. 1993). A similar trend occurred on Gran Canaria where the species was "easily sighted" until the middle of the $20^{\text {th }}$ century (Gurney 1927, Hemmingsen 1958), but was not recorded during the first population census (Delgado et al. 1993). On Lobos the species was not observed in 1987, although one pair was recorded breeding in an old nest of a Raven (Corvus corax) in 1990 (Delgado et al. 1993). On Manta Clara two adults were observed during the census in an area with suitable nesting sites, but breeding was not confirmed. Solitary individuals were observed in 
subsequent years, but no breeding behaviours were recorded (Delgado et al. 1993). On Alegranza Island two breeding pairs were regularly observed during 1988-1990 (Delgado et al. 1993). On Fuerteventura, Egyptian Vulture was well distributed throughout the island, except in the region between La Oliva and Lahares, and at El Jable (Delgado et al. 1993). Egyptian Vulture was considered 'fairly scarce' on Lanzarote, with an early estimation of about 6-7 breeding pairs (Trotter 1970). However, during the census in 1987, only two breeding pairs were confirmed (Delgado et al. 1993).

\section{Recent data}

A second census of the population was conducted during 1998-2001, and estimates the Canary Island population to comprise 130 individuals, including at least 23-25 breeding pairs. The majority of breeding pairs was found on Fuerteventura, except single pairs on Lanzarote and Alegranza. These figures represent a $30 \%$ decrease in the breeding population in 10 years (Donázar et al. 2002b). Birds from these islands wander onto Tenerife, El Hierro and Gran Canaria (See Bannerman 1963). A more recent survey reports a $90 \%$ increase in breeding pairs (42) since the 1998-2001 survey (Díez et al. 2008), and a post-breeding season population size of about 200 individuals, c. $45 \%$ of which were adults or subadults occupying territories (Mallo \& Díez 2009). According to the latest unpublished data, the population continues to grow; in 2016 there were 62 breeding pairs and a population of about $\quad 300 \quad$ individuals (https://www.4vultures.org/2016/08/19/update-onthe-endangered-canary-islands-egyptian-vulture-

guirre/). Although the population is increasing and a high percentage of territory-holders breed, many fail at egg stage. Productivity is between 0.45 and 0.63; breeding success is low (Donázar et al. $2002 \mathrm{~b}$ ), and the fledging rate is lower than for any other Egyptian Vulture population studied (Mallo
\& Díez 2009). Adult and immature annual survival rates are around $90 \%$, and immature survival may be enhanced by supplemental feeding at "vulture restaurants" (Donázar et al. 2002b). The main threats involve electricity infrastructure (collision and electrocution), poisoning, disturbance at nesting sites and effects of lead poisoning (Gangoso et al. 2009, Mallo \& Díez 2009).

\section{Cape Verde}

\section{Historical data}

Based on observations in 1951, Bourne (1955) states the Egyptian Vulture is: "Abundant around large towns, where up to 20 were seen together in the more squalid areas, and one or two pairs around most villages, but rare on the prosperous islands of Fogo and Brava, where there are only one or two pairs. Fifty birds were flushed from one of several roosts near Mindello on São Vicente, and there was a resident flock of 14 at Praia on São Thiego. Rather less than one bird in ten was immature". As recently as the 1980s the Egyptian Vulture continued to be "abundant" throughout the archipelago (Bannerman \& Bannerman 1968, Naurois 1985). A large decline probably started in the 1970s, with data from the end of $20^{\text {th }}$ century suggesting very low numbers (Hille \& Thiollay 2000, Freitas et al. in prep). Hazevoet et al. (1996) reported that by 1986-1993, groups of five or more were seen only on Santo Antão, and that the rate of decline was “alarming" (Hazevoet et al. 1996). During a kite (Milvus sp.) survey, none were seen on the islands of Sal, Santiago and Brava in 1999, but on Brava two individuals were seen two years earlier, and they persisted in small numbers on Santo Antão in 1999 (Hille \& Thiollay 2000). Barone \& Castillo (2000) stated that Egyptian Vultures might already have vanished from the islands of Sal, São Vicente and Fogo and Santiago, and may have been surviving only on Santo Antão, São Nicolau, Maio, Santiago and Brava. 


\section{Recent data}

Consistent with the historical data, Hille \& Collar (2011) suggest that the species has suffered widespread declines with breeding pairs found only on Santo Antão and Boa Vista. Egyptian Vulture has most probably been extirpated from 10 other islands (Sao Vicente, Santa Luzia, Branco, Raso, Sal, Maio, Santiago, Fogo, Ilhéus Rombos and Brava). On Santo Antão the population has declined by at least $50 \%$, and on Boavista only a few pairs were recorded (Hille \& Collar 2011). A recent study compiled all unpublished records of the species during 1998 - 2018, and conducted field surveys and interviews with local people on half of the islands (Freitas et al. in prep.). The results point to a dramatic population decline, even on Santo Antão, which was previously considered a stronghold. Egyptian Vulture is still present in low numbers on Boa Vista, Maio and Santo Antão, but extinct on all other islands. The most recent estimate is of 7-11 breeding pairs remaining on the archipelago (Freitas et al. in prep).

The species seems to have declined substantially after widespread chemical fumigation on the island in 1989 and 1990, aimed at controlling a desert locust (Schistocerca gregaria) plague (Freitas et al. in prep). Poisoning appears to be one of the main threats: one adult pair was found poisoned in the nest in Maio island in 2002-2004 (S. Thomsett, in litt.), and poisoning was suggested when two other vultures were found dead next to a dead cat at the Santo Antão rubbish dump in 2000 (Hille \& Collar 2011). Poisoning against dogs, including the use of strychnine, still occurs, and a great variety of pesticides are still used in agriculture, (Freitas et al. in prep). Reduced food availability, due to improved sanitation around villages, closing of old refuse dumps and the abandonment of domestic cattle slaughter might also be affecting the population negatively (Freitas et al. in prep).

\section{The Gambia}

\section{Historical data}

The species has never been recorded as breeding in the country; it is considered a vagrant, with only six records between 1913 and 1990 (Gore 1990). During the next seven years there were four records from Western and Lower River regions, and only one record outside these areas - a subadult in flight over river N'jau in Central River Region. It is likely that these observations were all of Palaearctic migrants (Barlow et al. 1997, Crewe 2001, Caucanas et al. 2018).

\section{Recent data}

There are no confirmed observations of Egyptian Vultures in Gambia since 1997 (Caucanas et al. 2018)

\section{Ghana}

\section{Historical data}

We found no records of Egyptian Vultures in Ghana, except that by Harvey \& Harrison (1970): "an adult well seen flying north along Mole scarp on 9 August 1968". However, 40 years later, Dowsett et al. (2008a) commented on the validity of this observation, stating that "the sighting should not be accepted as the only record for Ghana in the absence of supporting information, despite its inclusion by Grimes (1987)".

\section{Recent data}

There are no published recent observations of Egyptian Vulture in Ghana.

\section{Guinea}

\section{Historical data}

Morel \& Morel (1985) mentioned observations of 
adult Egyptian Vultures sitting on the cliffs at Koundara, where suitable breeding habitat exists. One adult female, which was obtained in Senegal near the Guinean border in March 1972, was dissected and turned out to have $8 \mathrm{~mm}$ ovules and it was assumed to be a local breeder (Morel 1985). However, the species was not recorded during an approximately two-month survey period in the north-east of the country (Kankan and Beyla) (Walsh 1987).

\section{Recent data}

A country-wide raptor road survey undertaken over 27 days during Feb-Mar 2006 did not record this species, and listed it as a 'missing' species that would have been expected within the area surveyed (Rondeau et al. 2008).

\section{Mali}

\section{Historical data}

Thiollay (1989) states that a few hundred Egyptian Vulture pairs breed in West Africa, mainly in western and central Mali. During a road count survey in 1973, Egyptian Vultures were found in the Tilemsy Valley (16) and Adrar des Iforhas (11), and breeding was confirmed (Thiollay 2006). The species was common in the Sahel to 21 degrees north latitude, and bred on cliffs at Hombori and Baoulé from August to December-January (Lamarche 1980).

\section{Recent data}

Moulin et al. (2001) mentioned the absence of vultures in Adrar des Iforhas in northeast Mali, and Clouet \& Goar (2003) subsequently recorded only occasionally single wintering Egyptian Vultures "in spite of the well preserved livestock pastoralism in the area". Rondeau \& Thiollay (2004) reported that the species is absent from various areas where it had been recorded in 1970, and in 2004 was found only near the inland portion of the Niger River delta and the cliffs at Gourma. Thiollay (2007) mentioned an $86 \%$ decline in the abundance of the species around its breeding cliffs in central Mali (Hombori-Douenza massif). However, in September 2006 two Egyptian Vulture pairs, one with a fledgling, were recorded near Tombori Tondo in the Hombori-Douenza massif (Clouet et al. 2009). Among the main threats are poisoning, reduced food availability, poaching and disturbance (Rondeau \&Thiollay 2004).

\section{Mauritania}

\section{Historical data}

Thiollay (1977) reports breeding at Zemmour, which is the only breeding record for the country.

\section{Recent data}

There are no recent observations suggesting breeding in Mauritania. However, possibly >1000 Egyptian Vultures winter in southern-most Mauritania (along the borders with Senegal and Mali), migrating from Western Europe (Spain, Portugal, France) (García-Ripollés et al. 2010, Kobierzycki 2017), and probably significantly fewer numbers migrate from the severely depleted northern African population (Morocco, Algeria).

\section{Niger}

\section{Historical data}

One nest with a grown juvenile was found in late May 1979 near the airport at Zinder (Giraudoux et al. 1988). Thiollay (1977) mentions 100-200 breeding pairs on the cliffs of the Aïr massif, between Mopti and Hombori (Mali) and from Kayes to Kita (Mali) to Kédougou (Senegal), but the exact numbers recorded at each site were not presented. In a 7-year avifaunal survey of Air massif, Newby et al. (1987) noted the Egyptian Vulture as a frequent breeding species that occurred throughout the year, and mentioned that "the 
mountainous areas provide ideal breeding sites". During long-term waterbird and raptor surveys between Boumba and Barou (SW Niger), Ambagis et al. (2003) did not record Egyptian Vultures from February 1995 to April 1999.

\section{Recent data}

Less than 20 years after the first survey of Air massif, no breeding pairs were recorded during eagle surveys from March to June 2004 (Rondeau \& Thiollay, 2004, Thiollay 2006), suggesting a severely depleted Egyptian Vulture population in the area, or even local extinction. During raptor road counts from Adrar to Tenere only one Egyptian Vulture was recorded in 2004 (vs. 75 in 1970s), but it was still common in the oases of Kawar (27 vs 38 in 1970s) (Thiollay 2006). During vulture surveys conducted in 2003-2004 in southern Niger, the Egyptian Vulture was not recorded (Rondeau \& Thiollay 2004). A single individual was observed in June 2014 about $35 \mathrm{~km}$ south of Tanout, but its age was not mentioned (Petersen et al. 2007). Wacher et al. (2013) recorded the species in 11 out of 32 half-degree squares during wildlife surveys in the Sahelian region of Niger. They recorded a cluster of regular encounters in the Termit Massif and Koutous hills (c. $120 \mathrm{~km}$ southwest of Termit), where the yearround presence of adults and occasional presence of immatures suggests a resident population (Wacher et al. 2013). Pairs were also observed at the rocky outcrops of Dibella and Agadem, east of Tin Toumma (Wacher et al. 2013). In 2018, seven occupied Egyptian Vulture nests were found in area of Kéllé in Zinder region (SCF unpublished data, http://lifeneophron.eu/en/news-view/504.html).

Carcass poisoning aimed at killing predators is still widely practised, and has had a detrimental effect on the vulture populations. In addition, although livestock is still abundant, changes in husbandry may have resulted in food shortages (Thiollay 2007). The use of vulture parts for belief-based medicine and 'muti' (Nikolaus 2001, 2006, Buij et al. 2016) is also a major threat, and vulture body parts are illegally exported to Nigeria to supply the local markets (Kret et al. 2018).

\section{Nigeria}

\section{Historical data}

In Nigeria there is only one breeding record of Egyptian Vulture, made during a bird survey in Kano State, north Nigeria, where Sharland \& Wilkinson (1981) found the species in "rocky hills near Kazaure where they possibly bred in January 1972". At least two pairs were known to be in neighbouring Cameroon in the area of Rumsiki peak on the border with Nigeria (Scholte 1998). In light of the lack of detailed studies and the existence of suitable breeding habitat in both countries along the border, perhaps a small resident breeding population occurred around Rumsiki historically. However, such speculation is undermined by the fact that Egyptian Vultures have not been recorded in suitable breeding habitat at a well-known Rüppell's Vulture (Gyps rueppelli) colony (In northwest Nigeria near the village of Kotorkoshi (also spelled Kwatarkwashi) (Serle 1943, Cook \& Mundy 1980). Elgood et al. (1994) described the Egyptian Vulture as an "uncommon resident mostly in arid savanna of northeast from Kazaure to Lake Chad, but also southward at Yola, Numan, Wase Rock and Ibi", all in the Benue valley, but the same authors also mention that "most records are from the dry season suggesting immigration from either the Palaearctic or northeast Africa". Green (1989) observed and photographed a "juvenile with other vultures" on the Gaji River floodplain in June 1986, and subsequently Elgood et al. (1994) assumed that this observation "suggests breeding there".

\section{Recent data}

There are no published recent observations of Egyptian Vultures that suggest breeding, but it is 
possible that a small resident population still persists in the Mandara Mountains on the border with Cameroon (Buij and Croes 2014).

Vultures of all species are in steep decline in Nigeria, with use in traditional/belief-based medicine and consumption by humans being considered the major threats (Nikolaus 2001, 2006, Hancock 2010, R. Buij et al. 2016). Vulture populations throughout the country are declining and in many areas are severely depleted (Nikolaus 2001, Hancock 2010), being now uncommon, even in the national parks (e.g. Yankari).

\section{Senegal}

\section{Historical data}

Morel \& Roux (1973) suggested that the Egyptian Vulture was probably resident in Senegal. Morel (1985) mentions the collection of an adult female near the border checkpoint Segou, in March 1972. The bird had a developed ovary and was considered to be resident, but it was unclear if it originated from Senegal or Guinea. The lack of evidence of breeding in Guinea suggests more strongly that this bird was Senegalese. Several other individuals had been observed at the same place, while in March 1984 one individual was repeatedly observed (Morel 1985). Suitable breeding sites are not rare in the region, but are dispersed throughout the area, far from each other. Thus, it is impossible to confirm whether breeding takes place in Senegal or in a neighboring country. Morel \& Morel (1990) considered the Egyptian Vulture to be a Palaearctic winter visitor and scarce resident in Senegal. An immature was observed on $3^{\text {rd }}$ July in Niokolo Koba National Park, which may have been from the local population (Thiollay \& Dupuy 1970). The authors suggested that individuals seen in the park may be also local breeders from Mali, where the species commonly bred in the area between Kita and Kayes. More observations are reported from Kolda and Niokolo Koba National Park during the
Palaearctic winter in the period $1984-1994$ (Sauvage \& Rodwell 1998). There were two more sightings from that period from Djoudj National Park in January 1991 and 1992 (Rodwell et al. 1996). All these records might refer to Palaearctic migrants rather than local breeders.

\section{Recent data}

No Egyptian Vultures were observed during bird surveys during July - August in 2003 and 2004 (Petersen et al. 2007). Caucanas et al. (2018) report 31 recent records of the species, suggesting that the Egyptian Vulture is a sporadic visitor in the north between Kebemer and Richard Toll, and possibly further up in the middle Senegal valley. However, the majority of these records (21) are from eastern Senegal, mainly Boundou Community Nature Reserve. There are only two records outside these areas, from the Saloum delta and Basse-Casamance (Caucanas et al. 2018). The largest congregation, consisting of 30 vultures, was observed on 26 November 2017 at the Faleme River, in the extreme southeast of the Boundou Community Nature Reserve (Caucanas et al. 2018). All those birds were considered Palaearctic migrants, and there is no information on breeding of the species from Senegal.

Poisoning is among the main threats for the species in Senegal. Over 30 vultures and other raptors were found poisoned in 2015 near a cow carcass in Boundou Community Nature Reserve. Improvements in veterinary practices, the removal of carcasses, and the declines in wild mammal populations will act as limiting factors for the vulture populations in the near future (Caucanas $e t$ al. 2018).

\section{Togo}

\section{Historical data}

In the Atlas of Birds of Togo, Cheke \& Walsh (1996) mentioned one record of an individual in 
Fazao-Malfakassa National Park during MarchApril 1984, but it most probably refers to a vagrant bird.

\section{Recent data}

No breeding records for the species in Togo are known.

\section{$\underline{\text { Central Africa }}$}

Confirmed records of breeding Egyptian Vultures exist from the Saharo-Sahelian zone in northern parts of Central Africa - Chad and Cameroon (Fig. 3). Only three records come from Central African Republic, most probably of migrants; breeding has never been confirmed there. The species was considered abundant and widespread in Chad, breeding in Tibesti Massif, Ennedi plateau, Kilingen Mountains, and Hadjer al Hamis. However, current information on distribution and breeding in Chad is limited; most probably the population has declined severely during the last century. Recent observations suggest that a small resident population probably persists in the Mandara Mountains in north Cameroon.

\section{Cameroon}

\section{Historical data}

Scholte (1998) describes the first Cameroonian breeding record: "Egyptian Vultures were found throughout 1996-1997 near the famous Rumsiki

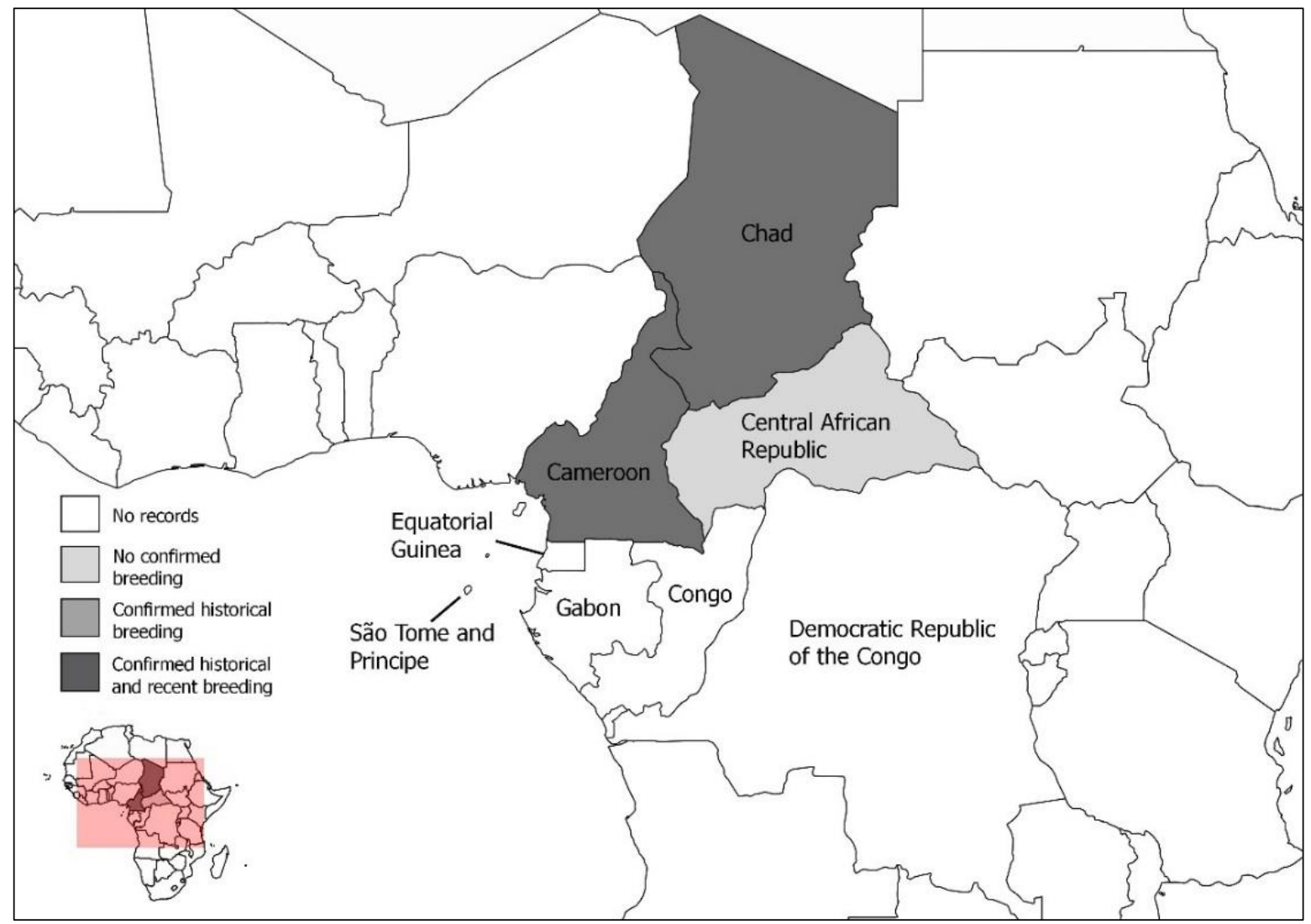

Fig. 3. Map of the Egyptian Vulture occurrence in Central Africa

peak in the Mandara Mountains west of Maroua at an altitude of $1100 \mathrm{~m}$. In September 1997 two adults were found sitting on a cliff of the Rumsiki peak and were observed from 15:00 onwards. At 16:00 a first-year juvenile joined them and started eating from "something" lying behind the two 
adults. The juvenile remained with the adults for the remaining observation time (until 16:30). Assuming the breeding period is at the end of the dry season, as occurred at Hadjer al Hamis, the young vulture is likely to have just flown".

\section{Recent data}

At least one pair has been frequently observed in the area of the Mandara Mountains, but on one occasion three adults were observed near a dead donkey (Buij \& Croes 2014). The observations were made in July - August and November 2005 2010. In Waza National Park an adult was observed in May 2007 and June 2008, and an immature in July 2010, which were most probably residents (Buij \& Croes 2014). These data suggest that a small resident population persists in Cameroon. (See also account for Nigeria above). However, body parts from various vulture species (presumably including Egyptian Vulture) are sold in markets in the region for belief-based healing purposes, and highlights a major threat to vultures in Cameroon (and elsewhere in Africa) (Nikolaus 2001). Vultures are killed by poisoning of waterholes or via poison baits, but they are also shot and trapped (Buij \& Croes 2014).

\section{Central African Republic}

\section{Historical data}

Egyptian Vulture has never been recorded as breeding in the country. There are two reported observations prior to 1978: one from Manovo Gounda Saint Floris National Park and one individual observed west of Bria (Snow 1978). In the early $80 \mathrm{~s}$ one individual was observed in Manovo Gounda Saint Floris National Park, but breeding has never been confirmed (Carroll 1988).

\section{Recent data}

We found no recent published records of the species for Central African Republic.

\section{Chad}

\section{Historical data}

Egyptian Vulture was recorded breeding in the Tibesti massif and on the Ennedi plateau (Snow, 1978, Mundy et al. 1992, J. Tubiana pers. comm.), where it prefers the lower elevations near human habitation (Guichard 1955). Guichard (1955) saw it "commonly scavenging around Zouar and Bardai in Tibesti", while J. Tubiana (pers. comm.) described it as "the most common bird of prey in Tibesti and Ennedi". Breeding has also been recorded twice elsewhere: once in the Kilingen Mountains, near Abéché (Salvan 1967), and to the south of Lake Chad. The latter case is described by Scholte (1998): "The breeding observation on 7 April 1991 at the Hadjer al Hamis (Chad), about $10 \mathrm{~km}$ south of Lake Chad shore at an altitude of about $280 \mathrm{~m}$, is the first for Lake Chad Basin. On the eastern side of this inselberg I found a nest with one young of about 2 weeks old, on a ridge in a deep cave, about $4 \mathrm{~m}$ from the entrance. Although I returned in 1992 and 1993 to this site, no further nesting was observed". Scholte (1998) also speculated that "although breeding has only been confirmed in Hadjer al Hamis and most likely in the Mandara Mountains, I expect all major mountain ranges to harbour a breeding population". It was reported as common and widespread in Ouadi Rimé - Ouadi Achi Faunal Reserve, frequenting the most arid regions during the wet season (Newby 1979), but not found breeding in the reserve. As part of a raptor survey during April 1973, Thiollay (1975) recorded only three Egyptian Vultures in Zakouma National Park, which possibly were migrants; none were recorded in Manda National Park.

\section{Recent data}

Wacher et al. (2013) recorded the species in 9 out of 89 half-degree squares during wildlife surveys in the Sahelian region of Chad. There was no evidence of breeding, and most observations were 
of individual immatures or small groups of 2-3 together on the grasslands of central Chad, typically associated with multi-species gatherings at livestock carcasses (Wacher et al. 2013). During the same survey, no Egyptian Vultures were recorded in the former breeding areas near Abéché. Notable concentrations of 9 in February 2011 and 22 (adults and immatures) in March 2013 were at the southern end of Bahr al Ghazal, with other vultures at a water-filled roadside borrow pit (Wacher et al. 2013). However, these observations most probably are of Palaearctic migrants. Satellite telemetry has revealed that Egyptian Vultures from the Balkans overwinter in Chad, and the majority of the juveniles spent $2-3$ years wandering across vast areas in Sahel, sometimes crossing national borders (Meyburg et al. 2004, Oppel et al. 2015, Buechley et al. 2018a). However, there are a few observations of adults in March - September (2013 - 2017) from areas with suitable breeding habitat in Guera region, which might refer to local breeders (Tim Wacher in litt.). In August 2018 adult, fledgling and immature were observed feeding at a carcass in Reserve de Faune de l'Ouadi Rimé-Ouadi Achim (Tim Wacher in litt.).

\section{$\underline{\text { East Africa }}$}

East Africa is considered to hold the largest breeding population of the Egyptian Vulture on the continent (BirdLife International 2018a, Porter \& Suleiman 2012). However, severe population declines due to poisoning and other human-related threats have been recorded in the past 50 years in some counties - Sudan, Kenya, Ethiopia, Somalia (Miskell \& Ash 1996, Nikolaus 2006, S. Thomsett pers. comm.) (Fig. 4). Socotra holds a vital and increasing population of about 800 pairs; the highest breeding density of the species in the world (Porter \& Suleiman 2012). Egyptian Vulture is considered widespread and is still regularly observed throughout the Horn of Africa and
Ethiopia. The species is common in northern Somalia, recorded near almost every village and town. In Djibouti Egyptian Vulture was reported as "the commonest raptor", and regularly recorded in many hilly and mountainous areas in the country (Jama 2010, Simoneau 1974, H. Rayaleh pers. comm.). However, the resident population size and its trend remain unknown in those countries, which are also a non-breeding season destination for migrants. In Kenya, Egyptian Vultures breed in the north, but previously reported population declines probably continue. In Tanzania and Uganda the Egyptian Vulture population has always been reported as small, and it is a rare breeder there

\section{Djibouti}

\section{Historical data}

Egyptian Vulture was reported as the "commonest raptor" (Simoneau 1974) and "extremely abundant" (Welch \& Welch 1984) in Djibouti.

\section{Recent data}

Djibouti is still considered to be home to a widespread resident breeding population of unknown size and trend, as well as annual migrants and temporarily resident subadults that should eventually move to Eurasia to breed (Welch et al. 2009, H. Rayaleh in litt.). However, declines have been reported in recent years (G. Mulholland in litt.). Egyptian Vultures are recorded year-round, almost anywhere near human settlements (i.e. nomad settlements, villages, secondary towns), except in Djibouti city where the presence of the Indian House Crow (Corvus splendens) may be excluding them (H. Rayaleh, pers. comm.). An estimate of breeding population size is difficult to make, $<50$ pairs has been suggested (G. Welch pers. comm.), but may be an underestimation. From 1999 to 2012, widely dispersed occupied nests were regularly recorded in many hilly and mountainous areas of the country, sometimes nesting near other 
vultures (e.g. Rüppell's and Griffon Vultures ( $G$. fulvus), Mount Arrey in Ali-Sabieh and Gamarré Plateau in Dikhil). In February 2006, one nest containing a large nestling, was found at Warabaley/Arrey Mountain, another nest at Wadi Holl-Holl/Bi' idley in Ali-Sabieh and two occupied nests at Wadi Bankoualé in Tadjoura were recorded (H. Rayaleh pers. comm.). An adult was observed at a probable breeding location in Lagada canyon near Randa village in January 2009 (A. Jama in litt.). One nest was found in March 2009 on cliffs in Wadi Eouâli, about $10 \mathrm{~km}$ NNE from Tadjoura (Welch et al. 2009). In February 2010, 10-15 Egyptian Vultures were seen in one day in the mountains of the Forêt du Day, but it is not known whether they were resident breeders or wintering birds (L. Nemeth, in litt.). In 2013, 30-50 Egyptian
Vultures could regularly be seen at the abattoir at Tadjoure, there were also some vultures using Tadjoura's rubbish dump (M. McGrady \& H. Rayaleh unpubl. data). A near-adult vulture tracked via satellite during 2013-14 did not migrate, but ranged over a large area that extended to northern Djibouti in the north and southeastern Ethiopia in the south (McGrady et al. 2019). Djibouti's importance to global conservation of Egyptian Vultures lies in its potentially large and stable breeding population, and its role as a safe wintering place and transit country for migrants. Currently, some of the threats that Egyptian Vultures face in other countries (e.g. poisoning, persecution) are generally not manifest in Djibouti, though development may heighten electrocution risk if unsafe infrastructure is used (McGrady et al. 2014).

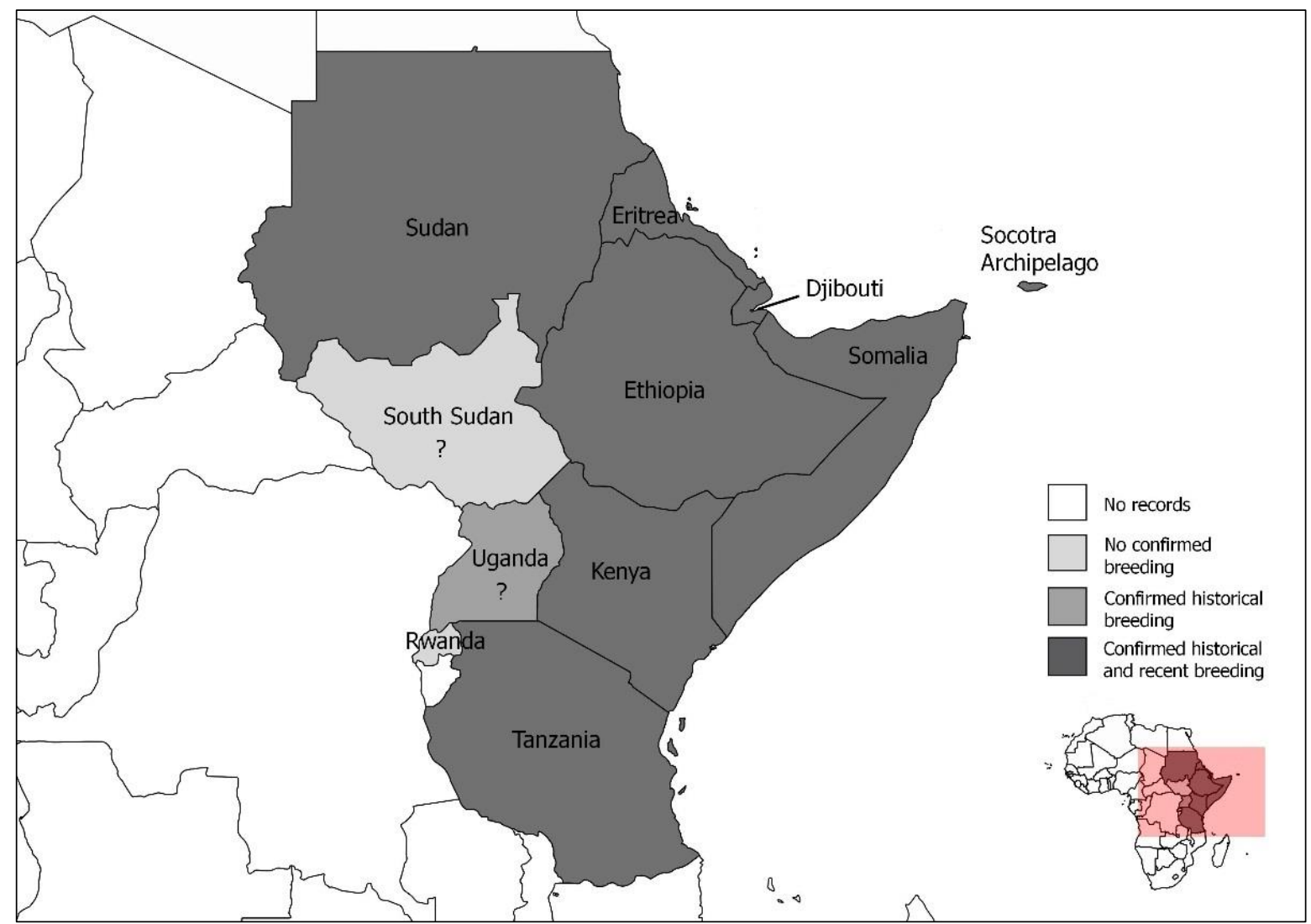

Figure 4. Map of the Egyptian Vulture occurrence in East Africa (? = recent or historical records of possible, but unconfirmed breeding).

\section{Eritrea}




\section{Historical data}

Smith (1957) described the Egyptian Vulture in Eritrea as "common throughout lowlands, Dancalia and islands". It wandered at times to the Central Plateau, and was seen in Asmara in winter, but these may have been Palaearctic migrants (Smith 1957). Occupied nests are known from Karora and Dahlac (Smith 1957). On the Dahlac archipelago during August-September 1962, individuals were occasionally recorded on the Nocra group of islands, close to human habitation (Clapham 1964). Ash \& Atkins (2009) mention a single breeding record in the extreme north of the country on the border with Sudan near Karora as described by Smith (1957). Tyler (1978) reported frequent observations of one pair, and possible breeding in the area of Fah, north of Nakfa. Despite recording 29 diurnal raptors, Zinner (2001) did not observe Egyptian Vultures during a long- term (1997-2000) primate survey in central and northern Eritrea.

\section{Recent data}

Recent observations in Eritrea are few, some of which might refer to migrants rather than residents. One adult was observed in June 2005 on the plains of Degra near the town of Segheneyt, south of the capital Asmara (S. Abraha pers. comm.). During April, September, October and December (20072009), four sightings were made of single adults and one of a pair (January 2009) perching on Rüppell's Vultures' whitewash on cliffs in the Adi Keih area. One sighting was of two adults circling together near Senafe (Feb 2009) (J. Anderson pers. comm.). During recent years, Egyptian Vultures have not been seen at the Asmara rubbish dump, which was regularly visited for bird observations (J. Anderson pers. comm.).

\section{Ethiopia}

\section{Recent data}

During surveys in 2009, 2010 and 2013, Egyptian Vulture was recorded, with a varying degree of probability of breeding, in 11 territories (V. Arkumarev, I. Angelov unpubl. data): Debre Libanos - two pairs, one building a nest and the second perching in the nest, nests were located on both sides of the canyon ; Debre Birhan - one pair standing on the ground close to the municipal rubbish dump; Ethiopian Highlands about $30 \mathrm{~km}$ south of Mount Abuna Yosef - one pair flying together over the road, east of Alem Ber, one adult roosting on a suitable breeding cliff that also held a Rüppell's Vulture colony; south of Bahir Dar - one adult vigorously chasing another high in the air; between Weldya, and Bahir Dar - one adult high over the road, descending towards gorge with suitable breeding cliffs; Liben plains east of Negele - one adult near a pastoralists' village (well known by the local people and said to be resident numbering at maximum several birds); several birds around Filtu; Lake Stephanie - three adults landing near supposed carcass with very suitable breeding cliffs nearby; El Sodo volcano crater in

South Ethiopia - pair arriving and perching together at the edge of the crater, later descending in direction towards the cliffs; near the village of 
Silsa in the Afar depression (local people mentioned the species to be resident and possibly breeding on the cliffs near the village, where we observed whitewash typical for the species). Egyptian Vultures also breed in low density in Semien National Park, where several pairs are known (Y. D. Abebe pers. comm.). Wilhelmi \& Kaariye (2006) mention it as "frequent - at least one seen weekly" and "often one of the first vultures appearing at carrion" in Ogaden region.

In the early 1980s, the Egyptian Vulture in Ethiopia was described as "probably decreasing slowly through improved sanitation but not at present threatened" (Brown et al. 1983). However, declines have been reported in recent years (G. Mulholland, in litt.), while Ash \& Atkins (2009) mentioned the species as "frequently found dead". Based on this review, it appears that breeding Egyptian Vultures in Ethiopia are widespread, but rare, occurring at a low density.

\section{Kenya}

\section{Historical data}

Jackson (1938) stated Egyptian Vulture was always confined to the highlands and the Rift Valley; to the east or west it was more or less a straggler, but within the Rift Valley it was widely found in areas including Ngong, Kedong Valley, Naivasha, Baringo, Laikipia, Eldama Ravine, northern Ewaso Nyiro, Mt Suswa and Kisumu. Birds were mainly seen around animal enclosures with the more common Hooded Vulture (Necrosyrtes monachus); the largest number seen together was 20-30 near Ngong. At the time, Hooded Vulture numbers had been reduced by poisoning (Jackson 1938). Given the close association of Hooded and Egyptian Vultures at animal enclosures, one wonders how often Egyptian Vultures were also being poisoned at that time (van Someren 1956). Sightings during 1979-89 at Ngong, Naivasha, Masai Mara and Mt. Kulal in southern Turkana (Diamond \& Keith 1980,
Taylor 1982, Davey 1994) and breeding records at Athi River, Ngong Hills and Hell's Gate in Naivasha (Britton 1978) were testament to its continued persistence throughout much of its original Kenyan range in those years. However, more recent data indicate a precipitous decline. A 1996 study involving four breeding pairs in Hell's Gate National Park ended the following year when all individuals were poisoned during a single incident on the periphery of the park (M. Virani pers. obs.). In the same period two pairs were lost in Nakuru National Park, and two more at Soysambu. In the 1980s between Lewa and Kipsing there were pairs almost every $2 \mathrm{~km}$, which were also lost by the mid-1990s (S. Thomsett pers. comm.). In 1981 and 1982 Thouless et al. (1987) studied the stone-throwing behaviour of one immature and one adult Egyptian Vultures at four locations: Ewaso-Ngiro Swamp near Lake Magadi, Hell's Gate gorge near Lake Naivasha, Mt. Susua in the Rift Valley and enar Voi in the south-east. The species was recorded during an avifaunal survey at Mt. Kulal in 1998 (Borghesio \& Ndang'ang'a 2001).

\section{Recent data}

At present pairs are most frequently sighted around livestock enclosures in northern Kenya around Marsabit, North Horr, Loylengalani, Laisamis and the Chalbi Desert, often with Hooded Vultures (D. Ogada unpubl. data). A few pairs roost and possibly nest at Kwenia in southwest Kenya ( $\mathrm{S}$. Thomsett pers. comm.). The birds are rare in Masai Mara, Tsavo National Park, and Samburu and Buffalo Springs National Reserves (D. Ogada unpubl. data). A juvenile bird was photographed in October 2018 near Soysambu, giving hope that the species still breeds there (S. Thomsett pers. comm.). A subadult bird was recorded during an aerial survey near Tsavo-Yata ridge in 2018 (S. Thomsett pers. comm.). It is believed that poisoning has probably played a major role in the 
large-scale disappearance of this species in Kenya. An extensive road count survey conducted in Masai Mara in 2003-2005 failed to record any Egyptian Vultures, while a survey along the same transect conducted in 1976 and 1988 resulted in 0.4 and 7.23 individuals per $100 \mathrm{~km}$ during the non-migration season and the migration season, respectively (Virani et al. 2011).

\section{Rwanda}

\section{Historical data}

The only record of this species is from a sighting of four birds in Kagera (now Akagera) National Park in January 1952 (Curry-Lindahl 1961). It is not clear if these birds were breeders or vagrants.

\section{Recent data}

To the best of our knowledge there are no recent published records of the species.

\section{Socotra archipelago, Yemen}

\section{Historical data}

The Egyptian Vulture has been common on Socotra at least since ornithologists first visited the island over 100 years ago (Porter \& Suleiman 2012). Ogilvie-Grant \& Forbes (1903) described it as "very common at all our campsites", and in 1964, Alec Forbes-Watson said it was "one of the most obvious birds on Socotra" (Ripley \& Bond 1966). Porter \& Suleiman (2012) stated: "Whilst they did not provide quantitative data, it is a reasonable assumption, given the current population, that there had been no major change over this period". In spring 1993, 618 Egyptian Vultures were recorded during a week-long survey, which covered parts of the northeast, central and southern plain (Kirwan $e t$ al. 1996).

\section{Recent data}

Egyptian Vulture on Socotra is considered entirely resident; it is the densest known population in the world and is estimated to comprise about 1900 individuals, perhaps 800 pairs (though all pairs may not be breeders) (Porter \& Suleiman 2012). Distribution of proven breeding corresponds to the distribution of limestone cliffs (Porter \& Quiroz 2010), and birds concentrate around the towns, where they take advantage of the regular supply of anthropogenic waste (Gangoso et al. 2013).

The Egyptian Vulture population on Socotra is healthy and numerous due to the absence of serious threats, the presence of plentiful food and the fact that it doesn't migrate into more dangerous areas. There is no persecution or disturbance, no evidence of direct or indirect poisoning, and no persistent pesticides are used in farming practices (Porter \& Suleiman 2012). There are no dogs or other predators on Socotra hence no human-carnivore conflict which probably explains the lack of poisoning incidents at rubbish dumps and near human settlements. However, rats are poisoned in the towns and this might be a threat in some places, but no effect on the population has been discerned (Porter \& Suleiman 2012).

\section{Somalia}

\section{Historical data}

Archer \& Godman (1937) wrote: "Wherever in Somaliland there are villages and the prospect of offal or refuse of any sort, there the Egyptian Vulture will be found". The same authors recorded the species breeding on the cliffs of the Golis range, Sheikh and Darass, but also at the base of the escarpment between Hudiso and Elgabobeh, where six nests containing eggs were found. Miskell \& Ash (1996) recorded the species distribution as mainly in the north, while south of $8^{\circ} \mathrm{N}$ there are relatively few records and none for breeding south of $1^{\circ} \mathrm{N}$. Numbers were presumably reduced as a result of an official countrywide poisoning (strychnine) campaign to control hyenas and jackals in the 1970s (Miskell \& Ash 1996). 


\section{Recent data}

In northern Somalia, twice in 18 months (2008 2009) large congregations of several hundred Egyptian Vultures (presumably resident) were observed at the rubbish dump in Burco, and another congregation was recorded in July 2008 at the Ceerigaabo rubbish dump (Jama 2010). However, the Erigavo rubbish dump was visited again in 2009 and it was found that the site had been cleared for development, and no vultures were observed (Jama 2010). Birds were consistently observed in and around almost every town and village between Burco and Ceerigaabo (e.g. Beer, Ina Afmadobe, Kirid, Wadamo Go, Oog) (Jama 2010). Reports are that it is very rare west of $45^{\circ} \mathrm{E}$, rare in the central parts, and more common in the east (Jama 2010).

\section{Sudan and South Sudan}

\section{Historical data}

The Egyptian Vulture has undergone a dramatic decline in Sudan (Wilson 1982, Nikolaus 1984).

Butler (1905) describes the Egyptian Vulture in Sudan as "extremely plentiful over all the northern parts of the country, breeding in the early spring on the rocky "jebels" of the desert or on trees near villages". Rothschild \& Wollaston (1902) describe it as "exceedingly common" in a small area of the Nile near Shendi. Butler (1905) also states that "in Khartoum, where these vultures abound, they pass the early hours of the morning in scavenging about the streets. During the heat of the day they collect in great numbers on the sandbanks of Tuti Island, opposite the town, where they sit in rows along the water's edge, drinking occasionally". At that time there was a large urban nesting population in Khartoum (G. Nikolaus in litt.). Cave \& Macdonald (1955) described it as "a very common resident throughout, but more common in the north than in the south". More recently, Nikolaus (1984) mentioned that the species has a major breeding population in northern Sudan. Hogg (1950) confirmed breeding of the Egyptian Vulture at two locations: between Atbara and Khartoum on 4 April ("eggs hatching") and "building of nest" on 29 April near Dilling in the Nuba Mountains. Nikolaus (1987, 1989) mentions the following breeding locations: Red Sea Hills west of Port Sudan; Eastern slopes of Jebel Sabidana; Eastern side of Jebel Hamoyet; surroundings of Basunda-north of Dinder National Park; the area of Jebel Sebaluga and Jebel Gerri; and uncommon north of Malakal and the Ilemi Triangle. Nikolaus (1987, 1989) mentioned that "numbers have decreased, noticeable in most areas except the Red Sea region, where Palaearctic migrants are expected" and classified the species as "still fairly common", while for the south of Sudan he categorized it as "uncommon".

\section{Recent data}

During 572 days spent in extreme southeast of South Sudan (January 2004 - January 2006), De Bont (2009) stated: “observed in small numbers (45 in total, both adults and juveniles) in all months except April and July. Most were seen in March (11). However, it is uncertain if those birds were Palaearctic migrants or residents. C. Chatham (pers. comm.) photographed an adult on a nest at one of the Pyramids of Meroe close to Shendi in February 2008. At the same location one active nest had been found a century earlier (Rothschild \& Wollaston 1902). Breeding might occur within 30$40 \mathrm{~km}$ of Nanyangacho $\left(05^{\circ} 30^{\prime} \mathrm{N} 34^{\circ} 46^{\prime} \mathrm{E}\right)$ in South Sudan (De Bont 2009). In September 2010 , breeding localities were found at a cliff north of Erheib (Red Sea Hills area) - a pair perching in a deep niche, very suitable for a nest and probably two neighbouring breeding territories in the mountains on the way to Khor Arba'At (northwest of Port Sudan) about $4 \mathrm{~km}$ east of the reservoir: one pair roosting in the evening at a traditional roost site (as suggested by whitewash) and another adult at 
another traditional roost site about $2 \mathrm{~km}$ from the first (Angelov \& Hashim 2019). Nikolaus (2006) visited northeastern Sudan in autumn 2005 after an absence of more than 20 years, and was astonished by the almost complete disappearance of vultures of all species. From the thousands of vultures reported in the early $20^{\text {th }}$ century around Khartoum and Wad Medani, there were only three pairs left in Khartoum in the late 1980s, and none were seen in 2005 (Nikolaus 2006).

\section{Tanzania}

\section{Historical data}

Until the 1970s the Egyptian Vulture in Tanzania was considered resident in small numbers in open country with rocky crags, mainly in arid and semiarid plateau country below $2000 \mathrm{~m}$ in northern Tanzania from Serengeti and Eyasi to Kondoa, Arusha National Park and Moshi (Britton 1980). Van Lawick-Goodall \& van Lawick-Goodall (1966) reported observations of one pair at Seronera in Serengeti and three individuals near Olduvai Gorge. In 1989 a group of 29 Egyptian Vultures was seen beside the river at the south end of Lake Natron (Turner \& Pearson 1991). In 1981 one individual was observed as far south as Mikumi National Park at $7^{\circ} \mathrm{S}$ (East African Bird Report 1981). In the 1990s it was reported to still occur in northern Tanzania from Arusha District west to the Serengeti plains and the Loliondo area (Selempo 1994, Zimmerman et al. 1996). In the Serengeti, Houston (1975) described it as a "dry-country bird, occurring in semi-desert conditions, nesting on cliff ledges. It was common only in the far eastern plains".

\section{Recent data}

In recent years the Egyptian Vulture observations are still mostly confined to the northern Rift Valley, from Arusha in the east to Serengeti and Mara River in the west. There are some irregular sightings from Ruaha National Park and Rukwa region, which are well south of the core range, and are most likely records of wandering individuals rather than of local breeders (Baker \& Baker 2018). Most of the records are from the Ngorongoro Conservation Area, south of Lake Natron and near Lake Eyasi. The species likely breeds on the Rift wall overlooking Lake Eyasi, but occupied nests have not been found yet. However, the number of breeding records and observed individuals in the past 10 years are far less than what was reported in the 80 s and 90s, suggesting an ongoing decline of the resident breeding population. The actual rate of decline remain unknown, but considering that the species has never been numerous and widespread in Tanzania it might be facing an increasing risk of extinction (Baker \& Baker 2018).

\section{Uganda}

\section{Historical data}

Egyptian Vulture was recorded as a resident breeder in east Uganda from Kidepo Valley National Park and East Chua south to Debasien Game Reserve, Mount Elgon and Tororo (Britton 1980,) but also in the west near Lake George (Carswell et al. 2005). Occasional observations at Kampala are possibly of wanderers from outside East Africa (Britton 1980). A single subadult was observed near Lake Kikorongo in Queen Elizabeth National Park in April 1998 (Rossouw 2001). The species nested on inaccessible cliffs in northeastern Uganda from October to December, and courtship behavior was observed near Mount Elgon (Carswell et al. 2005).

\section{Recent data}

In January 2003, one Egyptian Vulture was observed at a vulture restaurant in Queen Elizabeth National Park near Ishasha Lake flats (Pomeroy et al. 2004). However, it is not clear if it was a resident bird or a vagrant.

\section{Southern Africa}


Egyptian Vulture was considered widespread but never common in Southern Africa in late $19^{\text {th }}$ - early $20^{\text {th }}$ centuries (Roberts 1924). Confirmed breeding records exist only from South Africa, but there are numerous observations of individuals of various ages across the whole region (Fig. 5). Mundy et al. (1992) estimated the population size for the whole of Southern Africa at about 10 pairs, but more recent surveys could not confirm this (Simmons \& Bridgeford 1997). Due to the frequent observations near Etosha National Park, it was assumed that there was a small resident population breeding in northern Namibia/southern Angola; a pair was once observed in suitable nesting habitat, but breeding was not confirmed (see below). The majority of observations were from Eastern Cape Province in South Africa, where the species bred in small numbers until early in the $20^{\text {th }}$ century. In the past 40 years there have been no records of possible breeding in South Africa, and Anderson (2000) listed the species as Regionally Extinct. However, numerous observations in recent years give hope that a small resident population survives and waits to be discovered.

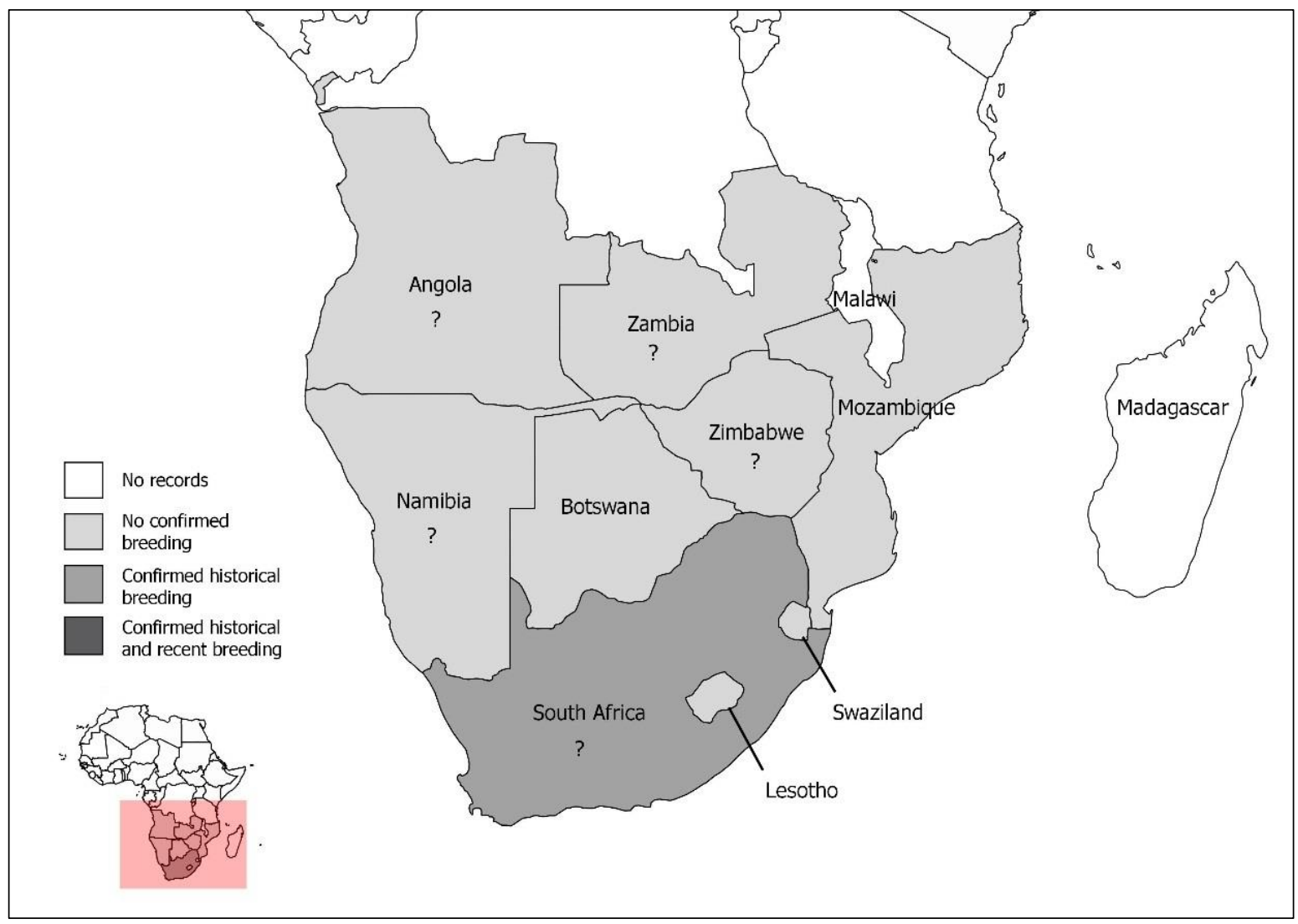

Figure 5. Map of the Egyptian Vulture occurrence in southern Africa (? = recent or historical records of possible, but unconfirmed breeding).

\section{Angola}

\section{Historical data}

The Egyptian Vulture in Angola is known only from the southern and west-central parts of the country (Brooke et al. 1971, Snow 1978, Mundy 
1978, Pinto 1983, Dean et al. 1988), and there is no evidence that it was ever common and widespread. It was considered to be uncommon in Acacia $s p$. and mopane (Colophospermum mopane) woodlands (Dean 2001). There are two records at suitable nesting sites, at the mouth of the Cuula River (Brooke et al. 1971), and at the mouth of the Quicombo River about $120 \mathrm{~km}$ north of the Cuula River (Dean 1974). It is uncertain whether the paucity of records reflects a small population size, or whether it has simply been under recorded (Dean 2001). There are no historical confirmed breeding records in Angola.

\section{Recent data}

No recent published records of the species in Angola were found.

\section{Botswana}

\section{Historical data}

There are only a few records of Egyptian Vultures in Botswana, Mundy (1978) does not mention any confirmed observations. The first confirmed observation is of a single immature, which was photographed in Chobe National Park in November 1988 (Matterson 1989); the second is of an adult seen near Macheneng in the Tuli Block in January 1990 (Hunter 1992, in Brown et al. 2000). However, Piper (2004) points out that those observations were made in boreal winter, and it is possible that they were of Palaearctic migrants that had come further south than most.

\section{Recent data}

Six Egyptian Vultures were observed at Mabuasehube Pan, Kgalagadi Transfontier Park on 2 October 2001, but this record remains unconfirmed (Anonymous 2002). There are no breeding records of the species in Botswana. A single individual was recorded at the Limpopo River near Stevensford Lodge in March 2005. A year later, not far away at Tuli block, one individual was observed in April and June (Roberts VII Multimedia Birds of Southern Africa, www.sabirding.co.za).

\section{Lesotho}

\section{Historical data}

Mundy (1978) mentions a single pre-1945 sighting of this bird in Lesotho.

\section{Recent data}

To the best of our knowledge there are no recent records of the species in Lesotho.

\section{Mozambique}

\section{Historical data}

Haagner (1945) reported the first observation of Egyptian Vulture in Mozambique near Beira. J.C. Sinclair saw an adult in Gorongosa National Park in December 1972 (Mundy 1978). After this, neither Clancey (1996) nor Parker (1999) make any mention of new records of the species.

\section{Recent data}

There were two sightings of single individuals (one adult and one juvenile) on the Pungwe Flats near Beira (Parker 2001). However, breeding has not been confirmed in Mozambique.

\section{Namibia}

\section{Historical data}

Clinning (1980) and Berry \& Berry (1983) first drew attention to a number of sightings in Etosha National Park. Since then, Simmons \& Bridgeford (1997) report a total of 27 sightings. The majority of the sightings were from Etosha, but some were from coastal regions (i.e. Henties Bay, mouth of the Ugab River, north of Swakopmund) and others from inland areas (i.e. Ganab, Gobaub). The majority of observations have been of immatures. In 1999 during a helicopter survey these and other 
sites were visited, but no Egyptian Vultures were observed (R. Simmons pers. comm.). Burger (1999) saw and photographed an immature bird over Mahango Game Reserve in November. Piper (2004) assumed there to be a reasonable possibility that the individuals seen in Etosha came from a small resident population in northern Namibia or even southwest Angola (see above). There is a suggestion that Egyptian Vultures possibly bred in 1990, when C.J. Brown observed a pair soaring near a suitable breeding cliff in the Kaokoveld Mountains, west of Etosha, though subsequent fieldwork could not confirm this (Piper 2004).

\section{Recent data}

Egyptian Vulture was observed in 2000 near Otjiwarongo, just outside Waterberg National Park (McKechnie 2000). In January and November 2001, two immatures were observed in Etosha (Simmons 2015), one near Namutoni, the other near Rietfontein waterhole. In January 2002 another immature was observed in Etosha, near Goas waterhole (Simmons 2015). In February 2018 an immature bird was observed near Windhoek, and in late October of that same year a second-year bird was photographed south of Etosha and some $60 \mathrm{~km}$ west of Okakuejo (H. Kolberg in litt.). However, no breeding has been confirmed. The observed young individuals were possibly Palaearctic migrants wintering further south than most.

\section{South Africa}

\section{Historical data}

The earliest sighting of Egyptian Vulture in South Africa that we could find was from the mountains around Cape Town in 1670, and it was common around ostrich (Struthio camelus) farms and rural villages of South Africa in the late 1800s and early 1900s (Mundy et al. 1992). At the same time the early explorer Johann Schreyer, wrote that Egyptian Vultures were "much esteemed by the
Hottentots, because they betray the lion by their presence when he has caught a prey" (in Mundy et al. 1992). During the 1780s François Levaillant stated that "one never comes across a single native settlement to which a pair of these birds has not attached itself" (Rookmaaker et al. 2004). However, the Egyptian Vulture very mysteriously disappeared from South Africa, with the last confirmed breeding in the Eastern Cape in 1923 (Roberts 1924). Mundy (1978) reviewed the data for the species between 1945 and 1978, and considered eight sightings during that time to be reliable. Subsequently, between 1978 and 1999 there have been at least 14 documented observations that included at least 17 individuals (Brown et al. 2000). In Limpopo Province an adult was observed near the Limpopo River in December 1974 (Mundy 1978). Two adults and an immature bird were recorded by different observers in January and February 1989, in the Langjan Nature Reserve (Lötter 1989). Two more sightings from Limpopo were reported by Hockey (1990) and Benson (1997), but with no supporting details. In Mpumalanga Province an adult was observed in Kruger National Park in 1977. Another observation of an adult flying over a carcass was made in Kruger in 1983 (Duplaix 1984). In Northwest Province there are three observations, one was of a four-year old bird at Lichtenburg (Ryan et al. 1997), and later of a juvenile bird at Lichtenburg Game Breeding Centre's vulture restaurant in December 1998 (Verdoorn 2004), and in October of the same year an adult was recorded near Tshukudu dam in Madikwe Game Reserve (Hofmeyer 1998). There have been only two sightings from the Northern Cape, one of an adult bird in Upington in 1973 (Mundy 1978), and one of an approximately 3 years-old bird on a farm "Voorloper" in the Kalahari (Anderson 1999). In Kwazulu-Natal two sightings were reported of single birds near Kokstad in 1964 and 1970. 
The majority of observations suggesting breeding are from Eastern Cape Province. Two pairs of adult birds were observed in Transkei in January 1977 (Mundy 1978). Barry (1987) reports seeing two pairs in Transkei in 1985 and 1986. Two observations of single adults were made at the Tina River bridge in 1997 and 1999 (Vernon \& Boshoff 1998, Brown 2000). Not far from there an adult was seen on the Qumba side of Tsitsa River in December 1982 (Quickelberge 1989). In the 1990s Vernon (2004) found a nest in a cave, which he considered belonged to a pair of Egyptian Vultures, but no potential breeders were present.

Mundy (1978) and Brown et al. (2000) do not report any sightings of the species in Western Cape and Free State Provinces between 1945 and 1999.

\section{Recent data}

Pienaar (2004) states that "although the species is listed as Regionally Extinct (Anderson 2000), it is frequently sighted and recorded in Langjan Nature Reserve near Vivo - close to Blouberg", in Limpopo Province. However, he refers to numerous sightings of the same individual. Kemp et al. (2001) consider the Egyptian Vulture to be a rare vagrant to the northern sector of the Kruger National Park, with an estimated population size of two individual birds. There is one recent record (2001) from Pilanesberg National Park between Bakubung Gate and Manyane Gate (Stumpf 2002). An immature Egyptian Vulture was observed in March and April 2001 near Vanzylsrust in Northern Cape (Anonymous 2001), and in December 2001 one individual was observed near Halcyon Drift in Eastern Cape Province (Vernon 2004).

Since 2005 there have been at least 15 more records of sightings of individual birds at various sites in the country, the most recent being a single immature bird that was recorded on numerous occasions in south-central Kruger National Park between May 2017 and October 2018. The most recent records and images of this bird indicate that it is moulting into sub-adult plumage (A. Botha pers. comm.). In the past 40 years there have been no records of possible breeding in South Africa, and Anderson (2000), and more recently Taylor et al. (2015), list the species as Regionally Extinct.

\section{Swaziland}

\section{Historical data}

Mundy (1978) mentions no historic sightings of the species in Swaziland. Ferreira (1999) describes an Egyptian Vulture feeding on a monitor lizard (Varanus sp.) at the foot of the Lebombo Mountains, in Hlane Royal National Park in March 1999. Nonetheless, there are no confirmed breeding records in Swaziland, and the bird observed in 1999 might have been a Palaearctic migrant that travelled further south than most (Piper 2004).

\section{Recent data}

We could find no evidence of recent records of Egyptian Vultures in Swaziland.

\section{Zambia}

\section{Historical data}

Dowsett \& Tree (1964) report two sightings in northern Rhodesia (now Zambia), one in May 1963 of an almost full adult at Ngosa Farm on the Kafue River in Western Province, and another in June of the same year of a full adult at Chapita Dam in the Eastern Province. However, Dowsett et al. (2008b) state that these sightings "are now believed to refer to Palm-nut Vulture". There are no confirmed historical breeding records.

\section{Recent data}

The only recent record in Zambia that we could find was in 2015 in the Lower Zambezi National Park (Riddell 2017), which appeared to be a juvenile, 
raising the question of whether it was the product of a local successful breeding.

\section{Zimbabwe}

\section{Historical data}

Buckley (1874) states: "I saw a few of these birds; but they were very scarce in comparison with the griffons". The historical scarcity of Egyptian Vultures in Zimbabwe is emphasized by the account of Marshall (2017). An adult Egyptian Vulture was observed at Wankie National Park in March 1961, flying over a buffalo (Syncerus caffer) carcass (Mundy 1978). Another adult and an immature were observed flying together near Gonarezhou Game Reserve (Mundy 1978). Kuilder (1989) observed one adult flying together with 10 African White-backed Vultures (Gyps africanus) at West Nicholson, south Zimbabwe, and at least one was seen at Plumtree (southwest Zimbabwe, near the border with Botswana) on 24 June 1993, but no details accompanied that record (Hustler \& Irwin, 1995). Between 1980 and 2000 there were sporadic sightings of single birds, both adult and juvenile (Marshall 2017). There are no confirmed historical breeding records in Zimbabwe, though Marshall (2017) suggests they may have been a very rare breeder near the Zambezi valley

\section{Recent data}

In recent times an immature bird was observed at Antelope Park, Gweru in December 2002 and January 2003, and an adult was photographed at Rusitu Forest in September 2003 (Feather 2003, Baker 2004, Mundy 2004). In 2016 an Egyptian Vulture was sighted at Mana Pools, and in 2017 an immature was seen at Manga 1 Pan in Hwange National Park (Long 2017); it is considered a very rare vagrant (Marshall 2017). There are no records of recent breeding.

\section{$\underline{\text { Threats }}$}

\section{Poisoning}

Poisoning is by far the most significant threat to vultures across Africa (Ogada et al. 2016), and human-wildlife conflict underlies the majority of vulture poisoning events, including those affecting Egyptian Vultures. Poisoning is also a complicated problem because it is driven by a variety of human motivations, and there is a wide variety of poisons and toxins that are involved. Egyptian Vultures scavenge not only on large carcasses but also on a wide variety of small food items, which makes them more susceptible to different types of poisoning than the large vulture species. Poisoning of Egyptian Vultures can be either accidental (including as secondary victims) or deliberate.

\section{Accidental poisoning}

\section{Poisoning from pesticides applied to agriculture}

Egyptian Vultures can be poisoned by pesticides used in agriculture. The intensification of agriculture in parts of Africa, notably cotton and rice, is associated with large-scale and increasing use of pesticides likely to affect raptor populations (Mullié \& Meininger 1985, Thiollay 2007). The application of pesticides may not be closely regulated, and this could contribute to the level of risk. Nikolaus (1984) considered the very intensive use of pesticides and herbicides around Khartoum and in Gesira Province as one of the reasons for the decline of the Egyptian Vulture in Sudan. Thiollay (1989) reported widespread aerial spraying against locusts and granivorous birds in Mali over a 3month period, during which huge numbers of raptors, storks, bustards and many other species were killed (although he does not say if vultures were also killed). On Cape Verde the species is reported to have declined after widespread chemical fumigation in 1989 and 1990, aiming at controlling a desert locust plague (Freitas et al. in prep). 


\section{Consumption of poisons laid for problem animals}

As in other parts of the world, poisons are intentionally used by farmers and herders to control wild or feral animals that cause damage to crops and livestock. When used for this purpose, vultures, including Egyptian Vultures, are typically not targeted, but are still killed accidentally (Carrete et al. 2007, Ogada et al. 2016, Botha et al. 2017). While carnivores are probably the most common target for such poisoning, a wide range of species are actually in the cross-hairs (e.g. poisoning against crocodiles (Crocodylus niloticus), hippopotami (Hippopotamus amphibius), warthogs (Phacochoerus africanus), quelea birds (Quelea sp.): Thomsett 1987, Keith \& Bruggers 1998, Otieno et al. 2010, Packer et al. 2011).

The most commonly used poisons are agricultural pesticides that have been repurposed to poison problem wildlife, and are used because they are typically easily available and inexpensive. Although such misuse of pesticides is illegal in the vast majority of African countries, implementation and enforcement of regulations is often weak (Botha et al. 2017).

Poisoning to eradicate wild carnivores has a long history throughout Africa (Brocklehurst 1931, Denney 1972, Watson 1986, Millington \& Tiega 1990, 1991, Frank et al. 2006), and it has been reported as the main threat to African vultures (Wilson 1982, Thevenot et al. 1985, Benson 2000, Ogada et al. 2012) and is still widely practised (Ogada 2014). In 1996 four Egyptian Vulture pairs were poisoned in a single incident in Kenya (M. Virani pers. comm.).

Though known to be 'common', many vulture poisoning incidents across the continent presumably remain unreported (Ogada 2014), and there are no quantitative data on the impact of this threat on the African Egyptian Vulture population, or indeed the migrants that arrive in Africa from
Eurasia. Though their resident Egyptian Vulture populations are small, the majority of reported vulture poisonings are from southern Africa, Kenya and Tanzania where, due to the large livestock and carnivore populations, human-carnivore conflict is severe.

Poisoning at dump sites for anthropogenic waste Effective management of anthropogenic waste (e.g. dump sites and landfills) is important because it can enhance human health. However, waste management activities can have a negative effect on scavenging birds, including Egyptian Vultures. Accidental poisoning of raptors at rubbish dumps is a particularly serious cause for concern in the Middle East (McGrady et al. 2019), due to the large number of open dumps where toxic waste may not be segregated, and the practice of leaving poison baits out for feral dogs (Tucker 2005). A similar state of affairs is likely to occur at dump sites in Africa. Egyptian Vultures are likely particularly susceptible to such poisoning because they regularly visit rubbish dumps near human settlements, feed on wide variety of small food items, and will consume poison baits (Carrete et al. 2007). In December 1970, three Egyptian Vultures were found dead at the town rubbish dump in Assab, South Eritrea (J. Ash in litt.), most probably poisoned, and another two were found at a rubbish dump in Cape Verde next to a dead cat (Hille \& Collar 2011). In Negele, Ethiopia c. 100 Hooded Vultures were found dead at a single roost tree in 2009, a few days after a mass poisoning campaign was mounted against feral dogs, in which more than 300 dogs were poisoned (I. Angelov pers. obs.). Abebe (2013) noted the recent poisoning of more than 12000 stray dogs within Addis Ababa, and the corresponding implications for the avian scavenger community. In Cape Verde poisoning targets dogs and cats, and has possible ramifications for scavenging raptors (Fergusson-Lees \& Christie 2001).. In Sierra Leone, due to the wholesale 
poisoning of rats, which are a problem in many areas of the country, secondary poisoning of vultures may also occur (Hancock 2010).

\section{NSAIDs as toxins}

Egyptian Vultures appear to be vulnerable to poisoning by non-steroidal anti-inflammatory drugs (NSAIDs), such as Diclofenac (Cuthbert et al. 2006), which have been linked to huge declines in vulture populations on the Indian subcontinent (Green et al. 2004, 2006, Oaks et al. 2004, Shultz et al. 2004). To date the effect of NSAIDs on African vultures, including Egyptian Vultures, is almost certainly less than in southern Asia. However, the risk of NSAID poisoning is thought to be highest in South Africa where veterinary intervention is probably relatively more common than in other parts of Africa, and scavenging bird feeding stations are stocked with farm animal carcasses that may contain residues of NSAIDs (Anderson et al. 2005). Elsewhere on the continent the NSAID threat to vultures is considered low because livestock carrion is often consumed by people, and not left to be scavenged (Richards \& Ogada 2015). Although considered less of a threat than other poisons, Porter \& Suliman (2012) warn about the potential of NSAIDs as a toxin in relation to the Egyptian Vulture population on Socotra, and such a warning could be applied to other parts of its African distribution e.g. Tanzania, Nigeria where Diclofenac was recently found on sale.

\section{Lead poisoning}

Vultures can also be poisoned when they consume the remains of lead ammunition in hunted animals (Watson et al. 2009), and from other sources (e.g. lead particles at rubbish dumps). The scale of lead poisoning in Africa is unknown, though it has been documented on the Canary Islands and Botswana (Donázar et al. 2002b, Kenny et al. 2015); it is a large problem for scavenging raptors in places outside Africa (e.g. Watson et al. 2009, Bounas et al. 2016, Plaza \& Lambertucci 2019). Vultures are known to consume 'junk', including potentially toxic items (Houston et al. 2007).

\section{Deliberate poisoning}

To the best of our knowledge there are no published records from Africa of the deliberate poisoning of Egyptian Vultures because they are considered a pest, though many poisoning incidents go unreported. The main potential reason for deliberate poisoning of Egyptian Vultures is to provide body parts for belief-based medicine and rituals, and to reduce detection of poaching activity (see below).

In parts of West and southern Africa vultures are deliberately poisoned, and their body parts are used for belief-based medicine and rituals (Buij et al. 2016, Cunningham \& Zondi 1991, Rondeau \& Thiollay 2004). A variety of pesticides are most commonly used as poisons, which are placed on whole animal carcasses or in small baits in areas frequently visited by vultures. (Ogada et al. 2014, Kret et al. 2018, Buij et al. 2016).

In recent years, vultures have been deliberately targeted by poachers of large animals because vultures coming down to poached animals may alert local authorities to the location of a kill (Ogada et al. 2015). While there is no documented evidence that this practice is killing Egyptian Vultures, it is likely that it could, and perhaps the lack of evidence is a product of under-reporting.

\section{Electrocution and collision with powerlines}

In areas where no cliffs exist Egyptian Vultures prefer to roost on power lines (especially, high voltage pylons), the biggest concentrations of which are recorded during the boreal winter (Mundy et al. 1992, Sigismondi \& Politano 1996, Donázar et al. 2002a), suggesting many are migratory, Palaearctic birds (Angelov et al. 2013, Arkumarev et al. 2014). The regular use of power lines, especially of medium voltage, for roosting 
means Egyptian Vultures are vulnerable to electrocution (Janss 2000). A single $30 \mathrm{~km}$ medium voltage power line in northeastern Sudan may have caused the death of hundreds, perhaps thousands of Egyptian Vultures over the past 50 years, and at least partially explains the population declines observed in the Middle East (Angelov et al. 2013). In the Afar depression, Ethiopia, local people confirmed the electrocution of several Egyptian Vultures near Metehara (Arkumarev et al. 2014). On the Canary Islands electrocution and collision with powerlines has also proved to be a major threat that limits the population (Donázar et al. 2002a). With the decline of the population and increase in the distribution and density of power lines across Africa, this threat is becoming much more serious (Smallie et al. 2009, Smallie \& Virani 2010). However, data are lacking for most of the Egyptian Vulture range in Africa (Rondeay \& Thiollay 2004, Thiollay 2007).

\section{Trade for fetish and bushmeat}

The use of vultures and their parts for bushmeat or in traditional, belief-based practices has deep roots in parts of West, northwest, Central and South Africa (Buij et al. 2016, Cunningham \& Zondi 1991, Rondeau and Thiollay 2004). In Morocco, traditional medicine has a definite impact on numerous species, particularly eagles and vultures (Thevenot et al. 1985). The killing of vultures for use in traditional practices is, at present, probably the biggest threat to vultures in many countries in West Africa, and body parts of vultures and other raptors are sold routinely in markets (Nikolaus 2001, Thiollay 2007, Buij et al. 2016).

Fetish demand and prices paid for vultures are particularly high in Nigeria (Nikolaus, 2011). Ninety-three vultures from six species (among which was a single Egyptian Vulture) were found during a survey of 24 fetish markets in Nigeria in 1999 (Nikolaus 2001). Nigeria seems to be the biggest market for vulture body parts used in traditional practices and bushmeat within West Africa, and Buij et al. (2016) estimated that up to 4 600 raptors are traded annually in Nigeria (Buij et al. 2016). While few Egyptian Vultures are found at markets during the surveys, this is likely a result of their rarity in West Africa rather than their desirability for use in traditional medicine and as food. A young Egyptian Vulture reared in Greece was killed for belief-based use in 2014 in Niger, and transported to be sold at a fetish market in Nigeria (Kret et al. 2018). Interviews with local people reveal that hunters from Nigeria are regularly hunting vultures and other raptors in Niger, and that they use a variety of techniques to secure them, including shooting, poisoning at carcasses and doping with tobacco and salt, which hinders flight (Kret et al. 2018). Another young Egyptian Vulture, released as part of a restocking program in Bulgaria, was killed for bushmeat in southern Niger in 2017 (Arkumarev et al. 2018a). As vulture populations in Nigeria are seriously depleted, traditional hunters and sellers of vulture parts are importing vultures and their parts from neighbouring countries extending the catchment area for the Nigerian market from Burkina Faso to Sudan (Nikolaus 2011, Saidu \& Buij 2013). However, the traders state that the origin of almost half of the vulture parts supplied to them is from within Nigeria (43.3\%), and the rest from other neighbouring countries - Niger (16.8\%), Benin (11.5\%), Sudan (8\%), Cameroon (7.1\%) and Chad (4.4\%). A group of poachers was arrested in central Chad in 2007 for trading in vulture parts, after poisoning about 20 Rüppell's and White-backed Vultures (H. Jazouli, in litt.). That group, which had been operating during the previous ten years, was exporting vulture parts from Chad to Niger $(\mathrm{H}$. Jazouli, in litt.).

\section{Shooting}

Deliberate shooting is a serious threat in some parts of Africa where raptors are killed for sport and to relieve boredom. A report from J. Svehlik in the 
mid-1980s stated that "everything that moves is shot at" in Libya (Meyburg \& Meyburg 1987). Two ringed Egyptian Vultures were found shot in Darfur, Sudan in 2013 (Hashim 2013). The author states: "Firearms are out of control in Darfur". Illegal shooting is of particular concern in Egypt. There are reports of carcasses of livestock being laid out at Lake Nasser to attract vultures for Maltese hunters to shoot (Baha el Din 2005). A video made by Maltese hunters shows how they shoot Egyptian Vultures and other birds at Lake Nasser, at least four vultures were killed during the filming (video available at www.youtube.com). An Egyptian Vulture reared in Greece was shot by a Nigerian hunter in south Niger with a hand-made rifle and was subsequently transported to Niger and sold for belief-based practices (Kret et al. 2018).

\section{Collision with windfarms}

Egyptian Vultures can be killed when they collide with wind turbines (e.g. Carrete et al. 2009, Martín et al. 2018). Although we are unaware of Egyptian Vulture deaths in Africa attributable to turbine collisions, little post-construction monitoring is being conducted (A. Camiña pers. comm.), and the development of wind energy on the continent is a looming threat (http://www.habitatinfo.com /vultures/maps/T4_turbines.jpg, Sanz-Aguilar et al. 2015). Large wind energy developments occur in various parts of Africa, and wind energy production will certainly expand in the future. Some operational wind farms are located where Egyptian Vulture (and other large soaring bird) migration concentrates (e.g. Egyptian and Sudanese Red Sea coast, Morocco south of Strait of Gibraltar), and these can be a threat to both resident vultures and migrants from Eurasia. Also, small windfarms (even single turbines) are sometimes seen as appropriate for the conditions found in parts of Africa. Such micro-schemes might pose a particular threat to Egyptian Vultures, given their mutualistic relationship with humans. Small developments that are widespread across the landscape could have a greater impact than fewer large developments, especially if the latter are located away from Egyptian Vulture migration corridors, and breeding and foraging areas. The expansion of wind farms in Africa could also increase the risk of collisions and electrocutions at associated electricity transmission and distribution infrastructure.

\section{Road kill}

Egyptian Vultures often feed on road-killed animals, which exposes them to the risk of being hit by motor vehicles. In Africa, Egyptian Vulture has been reported as road-killed in Ethiopia, Sudan and Socotra Island (Nikolaus 1984, Porter \& Sulieman 2012, J. Ash, in litt., Y. D. Abebe, in litt., Angelov \& Hashim 2019). In breeding areas traffic deaths could be an important limiting factor for already fragmented and isolated small populations, especially at sites close to heavily used roads.

\section{Discussion}

\section{Population status}

The review found information on Egyptian Vultures from 39 countries across Africa, including Socotra and the Canary Islands. We found no records of Egyptian Vultures in 16 other countries: Benin, Burundi, Comoro Islands, Côte d'Ivoire, Equatorial Guinea, Gabon, Guinea-Bissau, Liberia, Madagascar, Malawi, Mauritius, Republic of the Congo, Democratic Republic of the Congo, São Tomé and Príncipe, Seychelles and Sierra Leone (Morel 1985, Newman et al. 1992, Gatter 1997). In 12 countries where Egyptian Vultures have been observed, breeding has never been confirmed, and the observations most likely refer to vagrants or wintering individuals. For four countries (Angola, Namibia, Nigeria and Swaziland) there are no proven breeding records, but Egyptian Vultures have been observed in suitable breeding habitats 
during periods when the breeders are expected to be present on their territories, suggesting possible breeding. Furthermore, we found no post-2000 Egyptian Vulture observations for Angola, Nigeria or Swaziland suggesting that, despite historical breeding, it is likely extinct as a breeder in those nations. All recent records from Namibia are of immatures, and currently breeding is not suspected.

The information we were able to assemble supports the conclusion of other studies (Botha et al. 2017) that the Egyptian Vulture is in steep decline in most places in Africa, and adds detail to the geographic pattern of those numerical losses. The Horn of Africa (e.g. Ethiopia, Djibouti, northern Somalia) appears to be a relative stronghold, but there, too, losses almost certainly have occurred. The lack of data is pervasive and undermines assessments of the declines in all places, hindering conservation on every scale, including amongst continents due to the migration into Africa by northern breeding vultures from Europe and West Asia.

The greatest losses in distribution have probably occurred in Southern Africa, where resident Egyptian Vultures appeared to have always been sparse and where few, if any, migrants from Eurasia arrive after migrating. The losses in southern Africa have resulted in a large proportion of the historic Egyptian Vulture distribution in Africa being lost. However, numerically speaking, losses south of the equator probably represent a minority proportion of the resident African population.

In the first estimate of the size of the resident Egyptian Vulture population, Mundy et al. (1992) suggested that 7500 breeding pairs occurred on the continent (excluding Socotra and Canary Islands), from a total population of 20000 individuals. Later, based on observations of a few breeding pairs in northern Cameroon and western Chad, where the species was previously not known to breed, Scholte (1998) suggested that the whole African population may be larger, but Rondeau \& Thiollay (2004) later discussed Scholte's statement, suggesting that it "should be considered an overestimation". According to the most recent population estimation, about 1000 - 2000 Egyptian Vulture breeding pairs occur in Africa and about 800 pairs on Socotra Island (BirdLife International 2018a, Porter \& Suleiman 2012), suggesting a decline of about $75 \%$, at least, and Ogada et al. (2016) estimate an annual rate of decrease of ca $5.9 \%$ during the last 29-36 years. While there are some places where "new" breeding pairs or populations have been found (e.g. Amezian \& Khamlichi (2015) in Morocco, R. Tovey pers. comm. in Libya), in most if not all of these cases this is likely the result of past data deficiencies rather than any increase in numbers and distribution.

Due to lack of detailed information, it is difficult to determine where the greatest numerical losses of resident African Egyptian Vultures have occurred, perhaps in its namesake, Egypt, or in Mali, Sudan or Kenya (Rondeau and Thiollay 2004, Nicolaus 2006, Virani et al. 2011, M. Baha el Din in litt.). Recent road count surveys in Kenya and Mali reported Egyptian Vulture decline rates of $100 \%$ and 86.6\%, respectively (Virani et al. 2011, Rondeau \&Thiollay 2004). It should be acknowledgedthat these declines in Africa are matched or exceeded by declines elsewhere in the Egyptian Vulture's wide distribution; European populations have declined by $50-79 \%$ in the last 50 years (BirdLife International 2018a), the population on the Indian subcontinent has experienced a $90 \%$ decline over only a decade probably due to Diclofenac (Cuthbert et al. 2006), and remarkable declines have been reported also in most countries in the Middle East (Nikolov et al. 2016).

One needs to keep in mind that Africa is also important to migrant Egyptian Vultures. During every boreal winter an unknown number of migrants from Eurasia (estimated by Mundy et al. 1994 at 10 000) stay in Africa: those from Iberia, 
France and Italy mostly stay in sub-Saharan West Africa, and eastern European and western Asian migrants in sub-Saharan East Africa and the Horn of Africa (García-Ripollés et al. 2010, Oppel et al. 2015, Buechley et al. 2018b). Also, what appears to be a rather large proportion of juvenile migrants then dwell and mature in Africa for some years (Yosef \& Alon 1997, Oppel et al. 2015). Of course, during their time in Africa, these migrants are exposed to the threats existing in their African home ranges (Oppel et al. 2015, Kret et al. 2018).

\section{Threats}

The threats facing Egyptian Vultures in Africa (and other vultures), whether resident or migrant, are largely similar to those elsewhere, though in some cases they have characteristics that are geographically particular (Buij et al. 2016, Botha et al. 2017). Among the main threats to all vultures in Africa, Europe, Asia and the Middle East are poisoning, illegal killing and electrocution, but the magnitude and the relative importance of each of those threats at the Africa-continent scale are different from non-African countries (Botha et al. 2017). While in Europe the effects of these threats on Egyptian Vulture populations have been relatively well-studied and described (Iñigo et al. 2008), quantitative information about their impacts on the Egyptian Vulture populations in Africa is lacking. Under-reporting of Egyptian Vulture mortalities and their causes is a problem across the range (Botha et al. 2017), and is probably especially so in Africa.

Threats operating over large areas in Africa and persistent over time may have detrimental effects also on the wintering Egyptian Vultures originating from other populations. Africa harbours the majority of the European and some unknown proportion of the West Asian populations during the northern winter (García-Ripollés et al. 2010, Buechley et al. 2018a). Large congregations are reported from Ethiopia and Djibouti (McGrady et al. 2013, Arkumarev et al. 2014), but large numbers of migrants are wintering also over vast areas in the Sahel - Mauritania, Mali, Niger, Nigeria, Chad and Sudan (Oppel et al. 2015, Garcia-Ripolles et al. 2010).

Poisoning, whether accidental or on purpose, is considered the most significant threat across Africa to all vultures, including Egyptian Vulture (Botha et al. 2017). Certain life history traits (e.g. dietary breadth) and patterns of habitat use (e.g. commensal with humans in some places, use of rubbish dumps) may increase their susceptibility to poisoning (Donázar et al. 1996, Chhangani \& Mohnot 2008, Virani et al. 2011). Poisoning campaigns or events to control animals that cause financial loss and threaten human health sometimes result in incidental killing of vultures, and a similar scenario is played out in other parts of the Egyptian Vulture's global distribution (Iñigo et al. 2008, Cortes-Avizanda et al. 2009), however, some poisoning efforts in Africa aim to reduce detection of poached animals (Ogada et al. 2015) or obtain vulture body parts for the belief-based medicine and muti trade (Buij et al. 2016), which are largely not motivations for poisoning elsewhere in the world. Poisoning for obtaining body parts for belief-based use is prevalent across West and Southern Africa while the threat from poisoning by poachers is characteristic for areas in southern and eastern Africa. Unintentional poisoning as a result of human-carnivore conflict is widespread throughout the continent (Buij et al. in prep.).

Electrocution of Egyptian Vultures and other large soaring birds occurs in Africa (e.g. Angleov et al. 2013), as it does in other parts of the world (Botha et al. 2017), and vultures are prone to electrocution because they will perch on power lines, particularly in desert areas where no trees are available for roosting and near predictable food sources (Donázar et al. 2002a). Although no studies have been undertaken to determine their magnitude 
throughout the Egyptian Vulture range, electrocution events, as stated earlier, are certainly under-reported, and especially so in Africa. Except for the well-documented case of mass Egyptian Vulture electrocutions near Port Sudan (Angelov et al. 2013), we found only anecdotal information of other cases in other parts of Africa (though electrocutions of other vultures are documented in southern Africa, Boshoff et al. 2011, where Egyptian Vultures are rare). As electrification arrives in new areas of Africa the threat of electrocution will, almost certainly, increase (Smallie et al. 2009, Smallie \& Virani 2010), and put further pressure on both migrant and resident Egyptian Vulture populations.

Modern management and disposal of anthropogenic waste could result in less food being available to Egyptian Vultures, and theoretically limit population growth and size. In addition, rubbish dumps can act as a threat as they might offer food with high levels of different pollutants such as pesticides and heavy metals (TaulerAmetller et al. 2017). However, waste management that includes the segregation and proper disposal of toxic material and safe control of dogs (thereby benefitting human health) could provide a net benefit to scavenging birds (McGrady et al. 2019), including Egyptian Vultures.

\section{Research and conservation}

Given the critical status of Egyptian Vulture in almost its entire African range and in Eurasia, almost all imaginable research will (and should) be focused on conservation. Lack of data on the status of Egyptian Vulture in many parts of Africa, the complexity of threats they face in different parts, and financial costs are key impediments to conserving Egyptian Vultures in Africa. Because Africa is a destination for Eurasian migrating Egyptian Vultures impedements also hinder conservation of those populations. In the case of some of the threats faced by Egyptian Vultures (e.g. electrocution, collision with wind turbines, some poisoning) useful conservation activities can be initiated without having to wait on new research. However, sound research will need to be part of any conservation as a way of monitoring progress, and achieving cost-effective conservation in the medium to long term.

Knowing the status of Egyptian Vultures and their population trends in their African range is important. The Egyptian Vulture is an elusive species with low detection probability (relative to other raptors) during breeding (Mateo-Tomas 2009). Species and country-specific methodologies for monitoring should be applied in areas where Egyptian Vultures are extant. Developing longterm monitoring schemes in Africa, like those in parts of Europe, that use comparable methods for breeding territory monitoring, density and occupancy rate estimations, monitoring of breeding performance and threats (Avizanda et al. 2009, Sara et al. 2009, Arkumarev et al. 2018b) is important. However, given the condition of Egyptian Vulture populations in Africa and the current lack of human and financial resources to undertake comprehensive monitoring, it seems likely that prioritizing the monitoring in certain areas is necessary.

Electrocution is an important threat to Egyptian Vultures in Africa, about which we know too little. However, because electrification in many parts of Africa is in its infancy, the opportunity exists to get things right in the first place by installing bird-safe structures from the outset. In doing so fewer vultures would die, and savings (on maintenance) and better customer service could be realized by electricity companies. Where dangerous powerlines already exist in areas where concentrations of vultures occur (e.g. near rubbish dumps, in the Horn of Africa) remedial work can be prioritized and done, providing the most costeffective conservation benefit. An illustration of 
what can be achieved is seen in the case of a single powerline near Port Sudan that caused the death of probably thousands of Egyptian Vultures (Angelov et al. 2013). Sudan, a relatively poor country, took action and replaced the most dangerous stretch of cable with new, fully-insulated infrastructure (https://www.birdlife.org/africa/news/sudan-killerline-disconnected ). In doing so the deaths of vultures and other raptors have been prevented. While opportunities for immediate action to reduce electrocutions exist, in many areas it is important to assess the exact scale of this threat, and ground surveys that map hazardous powerlines in areas important to Egyptian Vultures should be conducted.

Poisoning is a multi-faceted problem, which can be intentional or incidental, direct or secondary. Poisoning can be driven by different human motivations, including protection of livestock and crops, promotion of human health benefits (e.g. poisoning of rats and dogs, exposing vultures to the potential for direct or secondary poisoning), hiding illegal activity, and providing material for beliefbased practices and medicine. More detailed studies are required to assess the impact on Egyptian Vultures of mass poisoning campaigns against stray dogs that occur at the rubbish dumps in many African countries (Abebe 2013). Mass mortality of Egyptian Vultures in stray dog poisoning campaigns are known from other parts of the species' range with the deadliest incident reported from Macedonia in 1992 when 60-70 Egyptian Vultures (half of the national population) were poisoned (Grubač 1997). Theconservation priority in the next decades will be the fight against the illegal use of poison. Effective regulation of the sale and use of legal agrochemicals known to be lethal to vultures should be adopted by countries, and campaigns to educate farmers on proper use and storage of legal poisons and pesticides should be undertaken.
Illegal killing of vultures and other raptors for belief-based rituals and for traditional medicine is an important threat, related to poisoning and shooting, which has caused severe declines to the targeted species in Western Africa (Buij et al. 2016). Recent reports have shown that birds originating from the Balkans fall victims to these illicit activities (Kret et al. 2018, Arkumarev et al. 2018a). These cases highlight the importance of Africa in the context of the global conservation of the Egyptian Vulture. Large scale awareness campaigns have to be specifically designed and implemented in areas where belief-based rituals that use vulture body parts occur. All relevant stakeholders (e.g. traditional healers, village chiefs, local hunters, representatives of the national authorities) should be targeted by these campaigns, and the approaches to different stakeholders should be tailored to address their interests. The benefits of the ecological services which vultures provide to the local communities must be emphasized.

Education is also key, and needs to be applied to a wide variety of groups, including but not limited to: farmers, consumers, electricity companies, government regulators and ministry officials, village and community leaders, teachers, politicians, and aid agencies. The Egyptian Vulture and the other vulture species should be presented as important ecosystem and cultural service providers hence converted into "flagship species" for conservation, environmental education and development of nature-based tourism. At the same time adequate legislation needs to be put in place and enforced, and harsher penalties need to be applied to those who break laws. Education is also important in addressing the growing impact of electrocution and collision with powerlines and wind turbines. Effective planning, design and mitigating measures can dramatically reduce the impact of energy infrastructure on avian populations (BirdLife International 2018b). The most hazardous powerlines across Africa have to be 
identified and mapped,, and mitigation measures must be applied in close collaboration and with the support of the local electricity companies and authorities. New powerlines in areas of high importance for resident or wintering Egyptian Vulture populations should make use of safe pylon types.

The action plan for the conservation of Old World Vultures covers multiple species, in recognition, in part, of the fact that different species are threatened by the same things (Botha et al.
2017). However, it also implies that solutions can benefit more than just one species or more than one population of individual species. For example, reducing electrocution risk for Egyptian Vultures will provide benefits to other vultures, and indeed other large soaring birds. Our study underscores the needfor immediate conservation action for the Egyptian Vulture, underpinned by more in-depth studies on their distribution, status, ecology and threats across Africa.

\section{Acknowledgements}

We acknowledge the help of Travis Rosenberry and Lloyd Kiff from the Peregrine Fund's Global Raptors Information Network (GRIN), who provided hundreds of difficult to find publications. We express our gratitude to the many local experts for sharing their personal observations, and making valuable comments on the country accounts and earlier versions of this manuscript, namely: A. Botha, A. Jama, A. Sigismondi, C. Cohen, C. Barlow, C. Chatham, D. Ogada, D. Pomeroy, E. Buechley, F. Liberatori, G. Mulholland, G. Nikolaus, G. Welch, H. Jazouli, H. Kolberg, H. Rayaleh, I. Hashim, J. Ash, J. Atkins, J. Tubiana, J. Anderson, J.-M. Thiollay, J. Brouwer, L. Nemeth, L. Palma, M. Baha el Din, M. Amezian, M. Clouet, M. Virani, N. Baker, O. Ridha, P. Hancock, P. Lopez, R. Porter, R. Tovey, R. Buij, R. Freitas, R. Porter, S. Baha el Din, S. Abraha, S. Messabhia, S. Thomsett, S. Tellailia, T. Wacher, W. Fremuth, Y. D. Abebe. Data for Egyptian Vulture observations in Chad and Niger were provided by The West African Bird DataBase at www.wabdab.org, managed by U. Liedén, T. Wacher and J. Brouwer, with T.Wacher, T. Rabeil, A. Matchano and A. R. M.Zabeirou (Sahara Conservation Fund) being the principal Egyptian Vulture record collectors. Data for Egyptian Vulture records within Africa wer provided by The African Raptor Databank at www.habitatinfo.com. We are very grateful to Rob Davies and one anonymous reviewer for providing constructive and helpful comments that improved the manuscript significantly.

\section{References}

Abebe, Y.D. 2013. Mass dog poisoning operation in Addis Ababa can have severe repercussions on vulture populations. Vulture News 64: 74-76.

Agudo, R., Rico, C., Hiraldo, F. \& Donázar, J.A. 2011. Evidence of connectivity between continental and differentiated insular populations in a highly mobile species. Diversity and Distributions 17(1): 1-12.

Ambagis, J., Brouwer, J. \& Jameson, C. 2003. Seasonal waterbird and raptor fluctuations on the Niger and Mekrou Rivers in Niger. Malimbus 25: 39-51.

Amezian, M. \& El Khamlichi, R. 2016. Significant population of Egyptian Vulture Neophron percnopterus found in Morocco. Ostrich 87: 73-76. 
Anderson, M.D. 1999. In van Rooyen, C. (Ed). Minutes of the Vulture Study Group Workshop 1999. Appendix 9: 1-2. Unpublished report.

Anderson, M.D. 2000. Egyptian Vulture. In: Barnes, K.N. (Ed). The Eskom Red Data Book of birds of South Africa, Lesotho and Swaziland, pp. 20. BirdLife South Africa, Johannesburg.

Anderson, M.D., Piper, S.E. \& Swan, G.E. 2005. Non-steroidal anti-inflammatory drug use in South Africa and possible effects on vultures. South African Journal of Science 101: 112-114.

Angelov, I., Hashim, I. \& Oppel, S. 2013. Persistent electrocution mortality of Egyptian Vultures Neophron percnopterus over 28 years in East Africa. Bird Conservation International 23: 1-6.

Angelov, I., Yotsova, T., Sarrouf, M. \& McGrady, M. J. 2013. Large increase of the Egyptian Vulture Neophron percnopterus population on Masirah Island, Oman. Sandgrouse 33: 140-152.

Angelov, I. \& Hashim, I. 2019. Birds of prey observed during vulture surveys in northeast Sudan. Scopus 39(2): $1-8$.

Anonymous 2001. Vulture snippets from around the world. Vulture News 45: 58-59.

Anonymous 2002. Six Egyptian Vultures seen in Botswana. Vulture News 46: 37.

Archer, G. \& Godman, E. M. 1937. The birds of British Somaliland and the Gulf of Aden. Gurney and Jackson, London.

Arkumarev, V., Dobrev, V., Abebe, Y.D., Popgeorgiev, G. \& Nikolov, S.C. 2014. Congregations of wintering Egyptian Vultures Neophron percnopterus in Afar, Ethiopia: present status and implications for conservation. Ostrich 85(2): 139-145.

Arkumarev, V., Dobrev, V., Stoychev, S., Dobrev, D., Demerdzhiev, D. \& Nikolov, S.C. 2018b. Breeding performance and population trend of the Egyptian Vulture Neophron percnopterus in Bulgaria: conservation implications. Ornis Fennica 95: 115-127.

Arkumarev, V., Mourtala, S.M., Rabeil, T., Apeverga, P. Dobrev, V. \& Nikolov S.C. 2018a. First release of captive bred Egyptian Vultures in Bulgaria. Technical report under action C3 the project LIFE16 NAT/BG/000874. BSPB, SCF \& APLORI. Sofia.

Ash, J.S. \& Atkins, J. 2009. Birds of Ethiopia and Eritrea: an atlas of distribution. Christopher Helm, London.

Baha el Din, M. 2005. National report on hunting - Arab Republic of Egypt. Report under the project LIFE04 TCY/INT/000054 Building capacity for sustainable hunting of migratory birds in the Mediterranean third countries.

Baha el Din, S. 2010. Where to watch birds in Wadi el-Gemal National Park and neighboring areas. Report under the Sustainable Economic Development in the Red Sea project.

Baker, C.T. 2004. Field Observations. Honeyguide 50: 221.

Baker, C.T. 2017. Field Observations. Honeyguide 63: 84-105. 
Baker, N.E. \& Baker, E.M. 2018. Birds of Tanzania: An Atlas of Distribution and Seasonality. http//tanzaniabirdatlas.net/nmaps.htm

Bannerman, D.A. \& Bannerman, W.M. 1968. Birds of the Atlantic Islands, vol. IV. A history of the birds of the Cape Verde Islands. Oliver \& Boyd, Edinburgh \& London.

Bannerman, D.A. 1963. Birds of the Atlantic Islands, vol. I. A History of the Birds of the Canary Islands and of the Salvages. Oliver \& Boyd, Edinburgh \& London.

Barlow, C., Wacher, T. \& Disley, T. 1997. A field guide to the birds of Gambia and Senegal. Pica Press, London.

Barone, R. \& Del Castillo, M.F. 2000. La avifauna nidificante del Archipiélago de Cabo Verde. Makanoresia 2: 45-55.

Barry, C.J. 1987. Egyptian Vultures. African Wildlife 41: 277-279.

Benson, P.C. 1997. Status of vultures in the Northern Province, South Africa. In: Bohsoff, A.F., Anderson, M.D., Borello, W.D (Eds). Vultures in the $21^{\text {st }}$ century: proceedings of a workshop on vulture research and conservation in southern Africa, pp. 21-29. Vulture Study Group, Johannesburg.

Benson, P.C. 2000. Causes of Cape Vulture Gyps coprotheres mortality at the Kransberg colony: a 17 years update. In: Chancellor, R. D. \& Meyburg, B.-U. (Eds). Raptors at Risk, pp. 77-86. World Working Group for Birds of Prey, Berlin.

Berry, H. \& Berry, C. 1983. Confirmation of Egyptian Vulture in the Etosha National Park. Madoqua 13: 321.

BirdLife International. 2018a. Species factsheet: Neophron percnopterus. www.birdlife.org. Accessed 20/10/2018.

BirdLife International. 2018b. BirdLife/IUCN Red List for birds. www.birdlife.org. Accessed 20/10/2018.

Borghesio L. \& Ndang'ang'a, P.K. 2001. An avifaunal survey of Mt. Kulal, Kenya. Scopus 22: 1-12.

Borrow, N. \& Demey. R. 2014. Birds of western Africa. Christopher Helm, London.

Boshoff, A.F., Minnie, J.C., Tambling, C.J., Michael \& M.D. 2011. The impact of power line-related mortality o the Cape Vulture Gyps coprotheres in a part of its range, with an emphasis on electrocution. Bird Conservation International 21: 311-327.

Botha, A.J., Andevski, J., Bowden, C.G.R., Gudka, M., Safford, R.J., Tavares, J. \& Williams, N.P. 2017. Multi-species Action Plan to Conserve African-Eurasian Vultures. CMS Raptors MOU Technical Publication No. 5. CMS Technical Series No. 35. Coordinating Unit of the CMS Raptors MOU, Abu Dhabi, United Arab Emirates.

Bounas, A., Ganoti, M., Giannakaki, E., Akrivos, A., Vavylis, D., Zorrilla, I. \& Saravia, V. 2016.

Bourne, W.R.P. 1955. The birds of Cape Verde Islands. Ibis 97: 508-556.

Britton H.A. 1978. E.A.N.H.S. nest record scheme: July 1976 - December 1977. Scopus 1: 132-141. 
Britton, P.L. 1980. Birds of East Africa: their habitat, status and distribution. East African Natural History Society, Nairobi, Kenya.

Brocklehurst, H.C. 1931. Game animals of the Sudan: their habits and distribution. Gurney \& Jackson, London.

Brooke, R.K., Cannell, C.I. \& Jeffery, R.D. 1971. New distributional records of raptors in western Angola. Bulletin of the British Ornithologists' Club 91: 165-167.

Brown, L.H., Urban, E.K. \& Newman, K. 1983. The birds of Africa. Academic Press, New York.

Brown, M., Forbes, D. \& Symes, C. 2000. Recent history of the Egyptian Vulture in southern Africa. Vulture News 42: 5-12.

Buckley, E.T. 1874. List of birds collected or observed during a journey into Matabili Country in 1873. Ibis 16(4): 335-391.

Buechley, E. \& Sekercioglu, C. 2013. Tracking Egyptian Vultures in the Middle East. ARGOS Forum 77: 17.

Buechley, E.R., McGrady, M.J., Coban, E. \& Şekercioğlu, C.H. 2018b. Satellite tracking a wide-ranging endangered vulture species to target conservation actions in the Middle East and East Africa. Biological Conservation https://doi.org/10.1007/s10531-018-1538-6.

Buechley, E.R., Oppel, S., Beatty, W.S., Nikolov, S.C., Dobrev, V., Arkumarev, V., Saravia, V., Bougain, C., Bounas, A., Kret, E., Skartsi, Th., Aktay, L., Aghababyan, K., Frehner, E. \& Şekercioğlu, C.H. 2018a. Identifying critical migratory bottlenecks and high-use areas for an endangered migratory soaring bird across three continents. Journal of Avian Biology. https://doi.org/10.1111/jav.01629.

Buij, R. \& Croes, B.M. 2014. Raptors in northern Cameroon, December 2005 - December 2010. Bulletin of the African Bird Club 21(1): 26-63.

Buij, R., Davies, R., Kendall, C., Monadjem, A., with Rahman, L. \& Luddington, L. In Prep. Vulture strongholds and key threats: a mapping exercise to guide vulture conservation in Africa.

Buij, R., Nikolaus, G., Whytock, R., Ingram, D.J. \& Ogada, D. 2016. Trade of threatened vultures and other raptors for fetish and bushmeat in West and Central Africa. Oryx 50: 606-616.

Bundy, G. 1976. The birds of Libya: an annotated check-list. British Ornithologists' Union, London.

Burger, P. 1999. Short note. Lanioturdus 32: 9-11.

Butler, A.L. 1905. A contribution to the ornithology of the Egyptian Soudan. Ibis 8(5): 301-409.

Carrete, M., Grande, J.M., Tella, J.L., Sanchez-Zapata, J.A., Donázar, J.A., Diaz-Delgado, R. \& Romo, A. 2007. Habitat, human pressure, and social behavior: partialling out factors affecting large-scale territory extinction in an endangered vulture. Biological Conservation 136: 143-154.

Carrete, M., Sánchez-Zapata, J.A., Benítez, J.R., Lobón, M. \& Donázar, J.A. 2009. Large scale riskassessment of wind-farms on population viability of a globally endangered long-lived raptor. Biological Conservation 142: 2954-2961. 
Carroll, R.W. 1988. Birds of Central African Republic. Malimbus 10: 177-200.

Carswell, M., Pomeroy, D., Reynolds, J. \& Tushabe, H. 2005. The bird atlas of Uganda. British Ornithologists' Club \& British Ornithologists' Union, Oxford.

Caucanas, G., Piot, B., Barlow, C. \& Phipps, W.L. 2018. A major count of the Egyptian Vulture Neophron percnopterus in Senegal in November 2017, with notes on its history and current status in Senegal and the Gambia. Malimbus 40: 55-66.

Cave, F.O. \& Macdonald, J. D. 1955. Birds of Sudan. Oliver \& Boyd, Edinburgh.

Ceccolini, G., Cenerini, A. \& Aebischer, A. 2009. Migration and wintering of released Italian Egyptian Vultures Neophron percnopterus. First results. Avocetta 33: 71-74.

Cheke, R.A. \& Walsh, J.F. 1996. The Birds of Togo: An Annotated Check-list. Tring: British Ornithologists' Union.

Chhangani, A.K. \& Mohnot, S.M. 2008. Demography of migratory vultures in and around Jodhpur, India. Vulture News 50: 23-34.

Clancey, P.A. 1996. The birds of southern Mozambique. Africa Bird Book Publishing, Westville.

Clapham, S.N. 1964. The birds of the Dahlac Archipelago. Ibis 106: 376-388.

Clinning, C.F. 1980. Sight records of the Egyptian Vulture from South-west Africa/Namibia. Madoqua 12: 63-64.

Clouet, M. \& Goar J.-L. 2003. L'avifaune de l'Adrar Tirharhar/Adrar des Iforas (Mali). Alauda 71: 469474.

Clouet, M., Goar, J.-L. \& Bousquet, J.-F. 2009. Note sur l'avifaune des massifs d'Hombori et Douentza (Mali). Malimbus 31: 47-54.

Cook, A.W. \& Mundy, P. J. 1980. Ruppell's griffon at Kotorkoshi, Nigeria. Malimbus 2: 102-105.

Cortes-Avizanda, A., Ceballos, O. \& Donazar, J.A. 2009. Long-term trends in population size and breeding success in the Egyptian Vulture (Neophron percnopterus) in northern Spain. Journal of Raptor Research 43: 43-49.

Cortez-Avizanda, A., Ceballos, O. \& Donázar, J.A. 2009. Long-term trends in population size and breeding success in the Egyptian Vulture (Neophron percnopterus) in northern Spain. Journal of Raptor Research 43: 43-49.

Cramp, S. \& Simmons., K.E.L. (Eds) 1980. Handbook of the birds of Europe, the Middle East and North Africa. Vol. 2. Hawks to bustards. Oxford University Press, London.

Crewe, M.D. 2001. Selected observations from The Gambia, 1997-1999, with comments on the identification of a number of species. Bulletin of the African Bird Club 8: 113-116.

Cunningham, A.B. \& Zondi, A.S. 1991. Use of animal parts for commercial trade in traditional medicines. Working Paper No. 76. Institute of Natural Resources. Pietermaritzburg. 
Curry-Lindahl, K. 1961. Exploration du Parc National Ablert et du Parc National de la Kagera. Fasc 1. Contribution a l'Etude des Vertebres Terrestres en Afrique Tropicale.

Cuthbert, R.J., Green, R.E., Ranada, S., Saravanan, S., Pain, D., Prakash, V. \& Cunningham, A.A. 2006. Rapid population declines of Egyptian Vulture (Neophron percnopterus) and Red-headed Vulture (Sarcogyps calvus) in India. Animal Conservation 9: 349-354.

Davey, P. 1994. Egyptian Vulture Neophron percnopterus behaviour. Scopus 18: 62.

de Bont, M. 2009. Bird observations from south-east Sudan. Bulletin of the African Bird Club 16: 37-52.

Dean, W.R.J. 1974. Breeding and distributional notes on some Angolan birds. Durban Museum Novitates 10: 109-125.

Dean, W.R.J. 2001. The distribution of vultures in Angola. Vulture News 45: 20-25.

Dean, W.R.J., Huntley, M.A., Huntley, B.J. \& Vernon, C. J. 1988. Notes on some birds of Angola. Durban Museum Novitates 14: 43-92.

Delgado, G., Carrillo, J. \& Nogales, M. 1993. Status and distribution of the Egyptian Vulture (Neophron percnopterus) in the Canary Islands. Biological Conservation 107(1): 89-97.

Denney, R. 1972. Relationships of wildlife to livestock on some developed ranches on the Laikipia Plateau, Kenya. Journal Range Management 25: 415-425.

Diamond, A.W. \& Keith, G.S. 1983. Avifaunas of Kenya forest islands. Mt. Kulal. Scopus 4: 49-55.

Díez, C., Mallo, M. \& Donázar, J.A. 2008. Seguimiento de la población de guirre (Neophron percnopterus majorensis) en la isla de Fuerteventura (Islas Canarias) (2004-2008). Informe final de Actividades y Resultados. Informe inédito. Estación Biológica de Doñana. C.S.I.C. Sevilla.

Donázar, J. A., Palacios, C.J., Gangoso, L., Ceballos, O., González, M.J. \& Hiraldo, F. 2002a. Conservation status and limiting factors in the endangered population of Egyptian Vulture (Neophron percnopterus) in the Canary Islands. Biological Conservation 107:89-98.

Donázar, J.A., Ceballos, O. \& Tella, J.L. 1996. Communal roosts of Egyptian Vultures (Neophron percnopterus): dynamics and implications for the species conservation. In: Muntaner, J., Mayol, J. (Eds). Biology and conservation of Mediterranean raptors, pp. 190-201. SEO BirdLife, Madrid.

Donázar, J.A., Negro, J.J., Palacios, C.J., Gangoso, L., Godoy, J.A., Ceballos, O., Hiraldo, F. \& Capote, N. 2002b. Description of a new subspecies of the Egyptian Vulture (Accipitridae: Neophron percnopterus) from the Canary Islands. Journal of Raptor Research 36: 17-23.

Dowsett, R.J. \& Tree, A.J. 1963. The occurrence of Neophron percnopterus in Northern Rhodesia. Bulletin of the British Ornithologists' Club 84: 52-54.

Dowsett, R.J., Aspinwall, D.R. \& Dowsett-Lemaire, F. 2008b. The birds of Zambia. Tauraco Press, Liège.

Dowsett, R.J., Dowsett-Lemaire, F. \& Hester, A. 2008a. The avifauna of Ghana: additions and corrections. Bulletin of the African Bird Club 15: 191-200.

Duplix, N. 1984. How rare is the Egyptian Vulture in SA? Vulture News 12: 12. 
El Agbani, M.A. \& Qninba, A. 2011. Les oiseaux d'intérêt patrimonial au Maroc. Publications du GREPOM no. 3. Rabat: GREPOM.

Elgood, J.H., Heigham, J.B., Moore, A.M., Nason, A.M., Sharland, R.E. \& Skinner, N.J. 1994. The Birds of Nigeria. British Ornithologists' Union. UK.

Etchecopar, R.D. \& Hüe, F. 1964. Les oiseaux du nord de l'Afrique.

Feather, P.J. 2003. An Egyptian Vulture an Antelope Park, Gweru. Honeyguide 49(1): 74-75.

Ferguson-Lees, J., Christie, D.A., Franklin, K., Mead, D. \& Burton, P. 2001. Raptors of the World. Houghton Mifflin Company, Boston.

Ferreira, M. 1999. More interesting observations: Egyptian Vulture Neophron percnopterus. Vulture News 41: 57 .

First confirmed case of lead poisoning in the endangered Egyptian vulture (Neophron

Frank, L., Hemson, G., Kushnir, H. \& Packer, C. 2006. Lions, conflicts and conservation in eastern and southern Africa. Eastern and southern African lion conservation workshop, Johannesburg, South Africa, 11-13 January 2006.

Freitas, R., Monteiro, C., Rodrigues, I., Tavares, A., Monteiro, G., López, P., Ferreira, J., Lima, L., Tavares, J. P. \& Palma, L. In prep. Cabo Verde Egyptian Vulture, on the brink: community perceptions, inferences and facts of an extreme population crash.

Gangoso, L., Agudo, R., Anadyn, J. D., De La Riva, M., Suleyman, A. S., Porter, R. \& Donazar, J. A. 2013. Reinventing mutualism between humans and wild fauna: insights from vultures as ecosystem services providers. Conservation Letters 6: 172-179.

Gangoso, L., Álvarez-Lloret, P., Rodríguez-Navarro, A.A., Mateo, R., Hiraldo, F. \& Donázar, J.A. 2009. Long-term effects of lead poisoning on bone mineralization in vultures exposed to ammunition sources. Environmental Pollution 157(2): 569-574.

García-Ripollés, C., López-López, P. \& Urios, V. 2010. First description of migration and wintering of adult Egyptian Vultures Neophron percnopterus tracked by GPS satellite telemetry. Bird Study 57: 261-265.

Garrido, J.R., Camiña-Cardenal, A., Guinda, M., Egea, M., Mouati, N., Godino, A. \& Paz de la Rocha, J.L. 2005. Absence of the Eurasian Griffon (Gyps fulvus) in northern Morocco. Journal of Raptor Research 39: 70-74.

Gatter, W. 1997. The Birds of Liberia. Yale University Press, New Haven.

Gaultier, T. 1985. Diurnal raptors in Tunisia: status and protection. Bulletin World Working Group for Birds of Prey 2: 61-66.

Giraudox, P., Degauquier, R., Jones, P.J., Weigel, J. \& Isenmann, I. 1988. Avifaune du Niger: etat des connaissances en 1986. Malimbus 10: 1-140. 
Goodman, S.M., Meininger, P.L., Baha el Din, S.M., Hobbs, J.J. \& Mullié, W.C. 1989. The Birds of Egypt. Oxford University Press, Oxford.

Gore, M.E.J. 1990. Birds of the Gambia. Checklist 3, 2nd ed., British Ornithologists' Union, Tring.

Green, A.A. 1989. Avifauna of Yankari Game Reserve, Nigeria: new records and observations. Malimbus 11: 61-72.

Green, R.E., Newton, I., Shultz, S., Cunningham, A.A., Gilbert, G., Pain, D.J. \& Prakash, V. 2004. Diclofenac poisoning as a cause of vulture population declines across the Indian subcontinent. Journal of Applied Ecology 41: 793-800.

Green, R.E., Taggart, M.A., Das, D., Pain, D.J., Sashi Kumar C., Cunningham, A.A. \& Cuthbert, R. 2006. Collapse of Asian vulture populations: risk of mortality from residues of the veterinary drug diclofenac in carcasses of treated cattle. Journal of Applied Ecology 43: 949-956.

Grimes, L.G. 1987. The Birds of Ghana: An annotated check-list. BOU Check-list No.9. British Ornithologists' Union, London.

Grubač, B. 1997. The Present Status of Vultures Aegypiinae in Central Balkans. Actas del II Congreso International Sobre Aves Carroneras, Canizares 93-103.

Guichard, K.M. 1955. The birds of Fezzan and Tibesti. Ibis 97: 393-424.

Gurney, G.H. 1927. Notes on birds observed at Orotava, Tenerife. Ibis 12(3): 634-644.

Gurney, J.H. 1876. Rambles of a naturalist in Egypt and other countries. Karrold \& Sons, London.

Haagner, A.K. 1945. A list of the birds observed in Beira and neighbourhood with some notes on habits, etc. Ostrich 16 (1): 32-43.

Hancock, P. (Ed) 2010. African Raptors. Newsletter of the African Raptor Network 3: 1-20.

Harvey, W.G. \& Harrison, I.D. 1970. The birds of the Mole game reserve. Bulletin of Nigerian Ornithological Society 7: 43-52, 63-75.

Hashim, M.I. 2013. Egyptian Vulture (Neophron percnopterus) survey in Sudan. Unpublished report under LIFE Project “The Return of the Neophron” (LIFE10 NAT/BG/000152), pp. 8.

Hasselquist, F. 1757. Iter Palaestinum. Lars Salvii, Stockholm.

Hazevoet, C.J., Fischer, S. \& Deloison, G. 1996. Ornithological news from the Cape Verde islands in 1995, including records of species new to the archipelago. Bulletin of the Zoological Museum of the University of Amsterdam 15: 21-27.

Heim de Balsac, H. \& Mayaud, N. 1962. Les Oiseaux du Nord-Ouest de l'Afrique. Distribution géographique, écologique, migrations, reproduction. Encyclopédie ornithologique-X. Lechevalier, Paris.

Hemmingsen, A.M. 1958. Field observations of birds in the Canary Islands. Vidensk. Meddr dansk. naturh. Foren 120: 189-206. 
Heuglin, T. von 1869. Ornithologie Nordost-Afrikas, der Nilquellen- und Küsten-Gebiete des Rothen Meers und des nördlichen Somal-Landes. Theodor Fischer, Cassel.

Hille, S. \& Thiollay, J.-M. 2000. The imminent extinction of the kites Milvus milvus fasciicauda and Milvus m. migrans on the Cape Verde islands. Bird Conservation International 10: 361-369.

Hille, S.M. \& Collar, N.J. 2011. Status assessment of raptors in Cape Verde confirms a major crisis for scavengers. Oryx 45(2): 217-224.

Hockey, P.A.R. 1990. Rare birds in South Africa - 1998. Sixth report of the SAOS Rarities Committee. Birding in South Africa 42: 34-38.

Hofmeyer, M. 1998. Egyptian Vulture seen at Madikwe Game Reserve. Vulture News 38: 27.

Hogg, P. 1950. Some breeding records from the Anglo-Egyptian Sudan. Ibis 92: 574-578.

Houston, D.C. 1975. Ecological isolation of African scavenging birds. Ardea 63:55-64.

Houston, D.C., Mee, A. \& McGrady, M. 2007. Why do condors and vultures eat junk?: the implications for conservation. Journal of Raptor Research 41: 235-238.

Hunter, N.D. 1992. Report from the Records Subcommittee. Babbler 24: 47-52.

Hustler, K. \& Irwin, M.P.S. 1995. Fifth report of the OAZ rarities committee. Honeyguide 41: 103-106.

Iñigo, A., Barov, B., Orhun, C. \& Gallo-Orsi, U. 2008. Action plan for the Egyptian Vulture Neophron percnopterus in the European Union. BirdLife International \& European Commission, Brussels.

Isenmann, P. \& Moali, A. 2000. Oiseaux d'Algérie/Birds of Algeria. Société d'études ornithologiques de France, Paris.

Jackson, F.J. 1938. The Birds of Kenya Colony and Uganda Protectorate. Volumes 1-3. Gurney and Jackson, London.

Jama, A. 2010. Somalia vulture survey. Unpublished report, pp. 2.

Janss, G.F.E. 2000. Avian mortality from power lines: a morphological approach of a species-specific mortality. Biological Conservation 95: 353-359.

Jennings, M.C. 2010. Atlas of the breeding birds of Arabia. Fauna of Arabia 25. King Abdulaziz City for Science and Technology, Riyadh, Kingdom of Saudi Arabia.

Jourdain, F.C.R. 1915. Notes on the bird-life of eastern Algeria. Ibis 3: 133-159.

Jourdain, F.C.R. 1935. Notes on a recent visit to Egypt and Palestine. Bulletin of British Ornithological Club 55: 168-170.

Keith, J. O. \& Bruggers, R.L. 1998. Review of hazards to raptors from pest control in Sahelian Africa. Journal of Raptor Research 32:151-158.

Kemp, A. \& Kemp, M. 1998. Birds of prey of Africa and its islands. New Holland, London. 
Kemp, A.C, Heroldt, I, Whyte, I. \& Harrison, J. 2001. Birds of the two largest parks in South Africa: a method to generate estimates of population size for all species and assess their conservation ecology. South Africa Journal of Science 97: 393-403.

Kenny, D., Reading, R., Maude G., Hancock, P. \& Garbett, B. 2015. Blood lead levels in White-backed Vultures (Gyps africanus) from Botswana, Africa. Vulture News 68: 25-31.

Kirwan, G.M, Martins, R.P., Morton, K.M. \& Showler, D.A. 1996. The status of birds in Socotra and 'Abd Al-Kuri and the records of the OSME survey in spring 1993. Sandgrouse 17: 83-101.

Kobierzycki, E. 2017. Bilan du programme de baguage - Suivi telemetrique du Vautout percnoptere (Neophron percnopterus) en France. Report 21 pp.

Kret, E., Rabeil, T., Muhammad, S.I., Shiwua, M., Hall, P., Arkumarev, V., Dobrev, V. \& Nikolov S.C. 2018. First documented case of the killing of an Egyptian Vulture (Neophron percnopterus) for beliefbased practices in Western Africa. Vie et Milieu/Life and Environment 68(1): 45-50.

Kretzmann, M.B., Capote, N., Gautschi, B., Godoy, J.A., Donázar, J.A. \& Negro, J. J. 2003. Genetically distinct island populations of the Egyptian Vulture (Neophron percnopterus). Conservation Genetics 4(6): 697-706.

Kuilder, J. 1989. Egyptian Vulture over southern Matabeleland. Honeyguide 35: 113.

Lack, D. \& Southern, H.N. 1949. Birds in Tenerife. Ibis 91: 607-626.

Lamarche, B. 1980. Liste commentée des oiseaux du Mali. Malimbus 2(2): 121-158.

Lavauden, L. 1924. Voyage de M. Guy Babault en Tunisie. OISEAUX. 280p.

Ledant, J.P., Jacob, J.P., Jacobs, P., Malher, F., Ochando, B. \& Roche, J. 1981. Mise à jour de l'avifaune Algérienne. [Update of the Algerian Avifauna.] Gerfaut 71: 295-394.

Levy, N. 1996. Present status, distribution and conservation trends of the Egyptian Vulture (Neophron percnopterus) in the Mediterranean countries and adjacent arid regions. In: Muntaner, J. \& Mayol, J. (Eds). Biology and conservation of Mediterranean raptors, pp. 13-33. SEO BirdLife, Madrid.

Loche, V. \& Bonaparte, C.L. 1958. Catalogue des mammifères et des oiseaux observés en Algérie. Bertrand, Paris.

Long, S. 2017. An Egyptian Vulture in Hwange National Park. Honeyguide 63: 71-72.

Lötter, G. 1989. Observations on Egyptian Vultures Neophron percnopterus at Langjan Nature Reserve Transvaal, South Africa. Vulture News 22: 34-38.

Mallo, M. \& Díez, C. 2009. 2009. El alimoche común en Canarias. In: del Moral, J.C. (Ed). El alimoche común en España. Población reproductora en 2008 y método de censo, pp 136. SEO/BirdLife. Madrid.

Marshall, B. 2017. The status of the Egyptian Vulture in Zimbabwe. Honeyguide 63: 72-73.

Martin, A. 1987. Atlas de las aves nidificantes el la isla de Tenerife. Instituto de Estudios Canarios. Monografia XXXII. Tenerife 275 pp. 
Martín, B., Perez-Bacalu, C., Onrubia, A., De Lucas, M. \& Ferrer, M. 2018. Impacts of windfarms on soaring bird populations at a migratory bottleneck. European Journal of Wildlife Research. Published online https://doi.org/10.1007/S10344-018-1192-Z.

Mateo-Tomás, P. 2009. Conservation and management of vultures in the Cantabrian mountains. PhD thesis, University of León.

Matterson, J. 1989. Egyptian Vulture in the Chobe National Park, Botswana. Vulture News 22: 62.

McGrady, M., Al Amri, T. \& Spalton, A. 2019. Protecting nature's waste managers. https://www.natureasia.com/en/nmiddleeast/article/10.1038/nmiddleeast.2019.80. Published 29 May 2019.

McGrady, M., Rayaleh, H., Abdillahi, E. \& Darar, A. 2013. Field report on migration counts at Ras Siyyan - Bab el Mandeb Strait, Djibouti, 2-10 March 2013 and fitting of GPS PTT to Egyptian Vulture at Tadjoura, Djibouti, 11-12 March 2013. Technical report. pp. 5.

McGrady, M.J., Karelus, D.L., Rayaleh, H.A., Sarrouf Willson, M., Meyburg, B.-U., Oli, M.K. \& Bildstein, K. 2019. Home range and movement of Egyptian Vultures in relation to rubbish dumps in Oman and the Horn of Africa. Bird Study 65: 544-556. https://doi.org/10.1080/00063657.2018.1561648.

McGrady, M.J., Rayaleh, H.A., Dara, A.M. \& Abdillahi, E. 2014. Migration of raptors across the Bab el Mandeb Strait, Djibouti, March 2013. Bulletin of the African Bird Club 21(1): 64-71.

McKechnie, A. 2000. Egyptian Vulture observation in northern Namibia. Vulture News 42: 46.

Meinertzhagen, R. 1930. Nicoll's Birds of Egypt. Vol. 2. Rees, London.

Messabhia, S., Ababsa, L. \& Saheb, M. 2018. First data on breeding ecology of the Egyptian Vulture Neophron percnopterus (Linnaeus, 1758) in Oum El Bouaghi cliffs (Eastern Algeria). World Journal of Environmental Biosciences 7(1): 59-63.

Meyburg, B.-U. \& Meyburg, C. 1987. Present status of diurnal birds of prey (Falconiformes) in various countries bordering the Mediterranean, pp. 147-152. In Baccetti, N. \& Spagnesi, M. (Eds.) Rapaci Mediterranei III. Supplemento alle Ricerche di Biologia della Selvaggina, Volume XII.

Meyburg, B.-U., Gallardo, M., Meyburg, C. \& Dimitrova, E. 2004. Migrations and sojourn in Africa of Egyptian Vultures (Neophron percnopterus) tracked by satellite. Journal of Ornithology 145: 273-280.

Meyburg, B.-U., McGrady, M.J. \& Sarrouf Willson, M. In press. Oman’s resident Egyptian Vulture Neopphron percnopterus population appears much larger than estimated. British Birds.

Meyburg B.-U., McGrady, M.J. \& Sarrouf Willson, M. In press. Oman's resident Egyptian Vulture Neophron percnopterus population appears much larger than estimated. British Birds.

Millington, S. J. \& Tiega, A. 1990. Biodiversity assessment of Niger. IUCN and Direction Faune Peche et pisciculture, Niger.

Millington, S. J. \& Tiega, A. 1991. Biological diversity in Niger. WWF report of USAIN. 
Miskell, J.E. \& Ash, J.S. 1996. Birds of Somalia. Yale University Press. New Haven.

Moali, A. \& Gaci, B. 1992. Les rapaces diurnes nicheurs en Kabylie (Algérie). Alauda 60: 164-169.

Morel G.J. \& Morel, M.-Y. 1988. Liste des oiseaux de Guinée. Malimbus 10(2): 143-176.

Morel, G.J. \& Morel, M.-Y. 1990. Les Oiseaux de Sénégambie. ORSTOM, Paris.

Morel, G.J. \& Roux, F. 1973. Les migrateurs paléarctiques au Senegal. Notes complémentaires. Terre et Vie 27: 523-545.

Morel, G.J. 1985. Les oiseaux des milieux rocheux au Senegal. Malimbus 7: 115-119.

Moulin, S., Dobigny, G., Cornette, R. \& Sidiyene, E.A. 2001. Observations ornithologiques dans l'Adrar des Iforas (Mali). Alauda 69: 527-532.

Mourtala, S.M. 2017. Compte-rendu de la mission de vérification en périphérie de la réserve de biosphère de Gadabedji au Niger d'un Vautour Percnoptère (Neophron percnopterus) muni d'émetteur GPS/satellite solaires. Ministère de l'Environnement et du Développement durable, Direction générale des eaux et forets, Direction de la faune, de la chasse et des aires protégées. République du Niger.

Mullié, W. C. \& Meininger, P.L. 1985. The decline of bird of prey populations in Egypt, pp. 61-82. In: Newton, I \& Chancellor, R.D. (Eds). Conservation Studies on Raptors. International Council for Bird Preservation, Cambridge.

Mundy, P. J. 1978. The Egyptian Vulture (Neophron percnopterus) in southern Africa. Biological Conservation 14: 307-315.

Mundy, P.J. 2000. The status of vultures in Africa during the 1990s, pp 151-164. In: Chancellor, R. D. \& Meyburg, B.-U. (Eds). Raptors at Risk, pp. 77-86. World Working Group for Birds of Prey, Berlin.

Mundy, P.J. 2004. The status of vultures in Zimbabwe. In: Monadjem, A., Anderson, M.D., Piper, S.E. \& Boshoff, A.F. (Eds). The Vultures of Africa - Quo Vadis? Proceedings of a workshop on vulture research and conservation in southern Africa, pp. 154. Birds of Prey Working Group, Johannesburg, South Africa.

Mundy, P.J., Butchart, D., Ledger, J. \& Piper, S. 1992. The vultures of Africa. Acorn Books, Randburg.

Naurois, R.D. 1985. La population de Neophron percnopterus Linne de l'Archipel du Cap-Vert. Sa Place parmi les peuplements de Vautors d'Afrique Occidengtale. Cyanopica 3: 245-268.

Newby, J., Grettenberger, J. \& Wakins, J. 1987. The birds of northern Air, Niger. Malimbus 9: 4-9.

Newby, J.E. 1979. The birds of the Oadi Rime - Ouadi Achim Faunal Reserve, a contribution to the study of the Chadian avifauna. Malimbus 1(2): 90-109.

Newman, K., Johnston-Stewart, N. \& Medland, B. 1992. Birds of Malawi: a supplement to Newman's Birds of southern Africa. Southern Book Publishers Halfway House, South Africa.

Nikolaus, G. 1984. Distinct status changes of certain Palaearctic migrants in the Sudan. Scopus 8: 36-38. 
Nikolaus, G. 1987. Distribution atlas of Sudan's birds with notes on habitat and status. Bonner zoologische Monographien 25: 1-322.

Nikolaus, G. 1989. Birds of South Sudan. Scopus Supplement 3: 1-124.

Nikolaus, G. 2001. Bird exploitation for traditional medicine in Nigeria. Malimbus 23: 45-55.

Nikolaus, G. 2006. Where have all the African vultures gone? Vulture News 55: 65-67.

Nikolaus, G. 2011. The fetish culture in West Africa: an ancient tradition as a threat to endangered bird life? In: Schychmann, K.L. (Ed). Tropical Vertebrates in a Changing World, pp. 145-150. Zoologisches Forschungsmuseum Alexander Koenig, Bonn.

Nikolov, S.C., Barov, B., Bowden, C. \& Williams, N. P. (Eds) 2016. Flyway action plan for the conservation of the Balkan and central Asian populations of the Egyptian Vulture Neophron percnopterus (EVFAP). BSPB Conservation Series No. 32, Sofia, CMS Raptors MoU Technical Publication No. 4, Abu Dhabi. pp. 124.

Oaks, J.L., Gilbert, M., Virani, M.Z., Watson, R.T., Meteyer, C. U., Rideout, B.A., Shivaprasad H.L., Ahmed, S., Chaudhry, M.J.I., Arshad, M., Mahmood, S., Ali, A. \& Khan, A.A. 2004. Diclofenac residues as the cause of vulture population decline in Pakistan. Nature 427: 630-633.

Ogada, D. L. 2014. The power of poison: pesticide poisoning of Africa's wildlife. Annals of the New York Academy of Sciences 1322(1): 1-20.

Ogada, D., Botha, A. \& Shaw, P. 2015. Ivory poachers and poison; drivers of Africa's declining vulture populations. Oryx 50: 593-596.

Ogada, D., Shaw, P., Beyers, R.L., Buij, R., Murn, C., Thiollay, J.M., Beale, C.M., Holdo, R.M., Pomeroy, D., Baker, N., Krüger, S.C., Botha, A., Virani, M.Z., Monadjem, A. \& Sinclair, A.R.E. 2016. Another continental vulture crisis: Africa's vultures collapsing toward extinction. Conservation Letters 9: 8997.

Ogada, D.L. \& Buij, R. 2011. Large declines of the Hooded Vulture Necrosyrtes monachus across its African range. Ostrich 82(2): 101-113.

Ogada, D.L., Keesing, F. \& Virani, M.Z. 2012. Dropping dead: causes and consequences of vulture population declines worldwide. Annals of the New York Academy of Sciences 1249: 57-71.

Ogilvie-Grant, W.R. \& Forbes, H.O. 1903. Birds of Sokotra and Abd-el-Kuri. In: Forbes, H.O. (Ed). The Natural History of Sokotra and Abd-el-Kuri, pp. 21-63. R.H. Porter, London.

Oppel, S., Dobrev, V., Arkumarev, V., Saravia, V., Bounas, A., Kret, E., Velevski, M., Stoychev, S. \& Nikolov, S.C. 2015. High juvenile mortality during migration in a declining population of a longdistance migratory raptor. Ibis 157(3): 545-557.

Otieno, P.O., Lalah, J.O., Virani, M., Jondiko, I.O. \& Schramm, K.-W. 2010. Carbofuran and its toxic metabolites provide forensic evidence for furadan exposure in vultures (Gyps africanus) in Kenya. Bulletin of Environmental Contamination and Toxicology 84: 536-545. 
Packer, C., Brink, H., Kissui, B.M., Maliti, H., Kushnir, H. \& Caro, T. 2011. Effects of trophy hunting on lion and leopard populations in Tanzania. Conservation Biology 25(1), 142-153.

Parker, V. 1999. The Atlas of the Birds of Sul do Save, Southern Mozambique. Avian Demography Unit and Endangered Wildlife Trust, Cape Town \& Johannesburg.

Parker, V. 2001. Vulture Study Group Mozambique Report. Vulture Study Group Workshop, Vulture Study Group, Lichtenburg.

percnopterus) in the Balkans. Vulture News 70: 22-29.

Petersen B.S., Christensen K.D. \& Jensen F.P. 2007. Bird population densities along two precipitation gradients in Senegal and Niger. Malimbus 29: 101-121.

Pienaar, K. 2004. The status and conservation of vultures in the Limpopo Province of South Africa. In: Monadjem, A., Anderson, M.D., Piper, S.E. \& Boshoff, A.F. (Eds). The vultures of Africa - Quo Vadis? Proceedings of a workshop on vulture research and conservation in southern Africa, pp. 106-108. Birds of Prey Working Group, Johannesburg, South Africa.

Pinto, A.A. da R. 1983. Ornitologia de Angola. Vol 1. Instituto de Investigacão Cientifica Tropical, Lisbon.

Piper, S. E. 2004. Egyptian Vulture Neophron percnopterus. In: Monadjem, A., Anderson, M.D., Piper, S.E. \& Boshoff, A.F. (Eds). The vultures of Africa - Quo Vadis? Proceedings of a workshop on vulture research and conservation in southern Africa, pp. 59-62. Birds of Prey Working Group, Johannesburg, South Africa.

Plaza, I.P. \& Lambertucci, S.A. 2019. What do we know about lead contamination in wild vultures and condors? A review of decades of research. Science of the Total Environment 654: 409-417.

Pomeroy, D., Christine, D., Anyii, P., Friday, T., Kaphu, G., Sande, E. \& Seifert, L. 2004. A vulture count in Uganda and suggestion to other vulture-counters. Vulture News 50: 29-33.

Porter, R.F. \& Quiroz, D. 2010. Social behaviour of the Egyptian Vulture. British Birds 103: 61-64.

Porter, R.F. \& Suleiman, A.-S. 2012. The Egyptian Vulture Neophron percnopterus on Socotra, Yemen: population, ecology, conservation and ethno-ornithology. Sandgrouse 34: 44-62.

Quickelberge, C.D. 1989. Birds of the Transkei. An ornithological history and annotated catalogue of all recorded species. Durban Natural History Museum, Durban

Richards N. \& Ogada D.L. 2015. Veterinary agents and poisons threaten avian scavengers in Africa and Europe. Royal Society of Chemistry Bulletin 17-19.

Riddell, I.C. 2017. An Egyptian Vulture at Mana Pools. Honeyguide 63: 71.

Ripley, S.D. \& Bond, G.M. 1966. The Birds of Socotra and 'Abd al-Kuri. Smithsonian Miscellaneous Collections 151(7).

Roberts VII Multimedia Birds of Southern Africa. Neophron percnopterus. www.sabirding.co.za. Accessed on 10/11/2018. 
Roberts, W.W. 1924. Egyptian Vulture nesting in the Transkei. Blythswood Review 1(3): 34.

Rodwell, S. P., Sauvage, A., Rumsey, S. J. R. \& Braunlich, A. 1996. An annotated check-list of birds occurring at the Parc National des Oiseaux du Djoudj in Senegal, 1984-1994. Malimbus 18(2): 74-111.

Rondeau, G. \& Thiollay, J.-M. 2004. West African vulture decline. Vulture News 51: 13-33.

Rondeau, G., Condeé, M.M., Ahon, B., Diallo, O. \& Pouakouyou, D. 2008. Survey of the occurrence and relative abundance of raptors in Guinea subject to international trade. JNCC report No. 412.

Rookmaaker, L.C., Mundy, P., Glenn, I. \& Spary, E. 2004. François Levaillant and the Birds of Africa. Johannesburg: Brenthurst Press.

Rossouw, J.D. 2001. New records of uncommon and poorly known species for Ugandan National Parks and Forest Reserves. Scopus 21: 23-34.

Rothschild, N. C. \& Wollaston, A. F. R. 1902. On a collection of birds from Shendi, Sudan. Ibis 8: 133.

Ryan, B., McLleron, G. \& Verdoorn, G.H. 1997. Egyptian Vulture at Lichtenburg Nature Reserve. Africa Birds and Birding 2(1): 15.

Saidu, Y. \& Buij, R. 2013. Traditional medicine trade in vulture parts in northern Nigeria. Vulture News 65: 4-14.

Salvan, J. 1967. Contributions a l'etude des oiseaux au Tchad. Oiseau et R.F.O. 37: 225-284.

Sanz-Aguilar, A., Sánchez-Zapata, J.A., Carrete, M., Benítez, J.R., Ávila, E., Arenas, R. \& Donázar, J.A. 2015. Action on multiple fronts, illegal poisoning and wind farm planning, is required to reverse the decline of the Egyptian vulture in southern Spain. Biological Conservation 187: 10-18.

Sara, M., Grenci, S. \& Di Vittorio, M. 2009. Status of Egyptian Vulture (Neophron percnopterus) in Sicily. Journal of Raptor Research 43: 66-69.

Sauvage, A. \& Rodwell, S.P. 1998. Notable observations of birds in Senegal (excluding Parc National des Oiseaux du Djoudj), 1984-1994. Malimbus 20: 75-122.

Scholte, P. 1998. Status of vultures in the Lake Chad basin, with special reference to northern Cameroon and western Chad. Vulture News 39: 3-19.

Selempo, E. 1994. Birds recorded from the Loliondo area of northern Tanzania. Scopus 17: 124-128.

Serle, W. 1943. Further field observations on northern Nigerian birds. Ibis 85: 264-300.

Sharland, R.E. \& Wilkinson, R. 1981. The birds of Kano state, Nigeria. Malimbus 3: 7-30.

Shultz, S., Baral H.S., Charman, S., Cunningham, A.A., Das, D., Ghalsasi, G.R., Goudar, M.S., Green, R.E., Jones, A., Nighot, P., Pain, D.J. \& Prakash, V. 2004. Diclofenac poisoning is widespread in declining vulture populations across the Indian subcontinent. Proceedings of the Royal Society London 271: 458-460. 
Sigismondi, A. \& Politano, E. 1996. Unusually high concentrations of Egyptian Vulture Neophron percnopterus in a border area of the Dancalia region of Ethiopia. It may be one of the most important wintering areas known. 2nd International Conference on Raptors 1996 - Urbino, Italy, pp. 88-89.

Simmons, R.E. \& Bridgeford, P. 1997. The status and conservation of vultures in Namibia, pp. 67-75. In: Boshoff, A.F., Anderson, M., \& Borello, W. (Eds). Vultures in the $21^{\text {st }}$ Century: proceedings of Workshop on Vulture Research and conservation in southern Africa. Vulture Study Group, Johannesburg.

Simmons, R.E., Brown, C J. \& Kemper, J. 2015. Birds to watch in Namibia: red, rare and endemic species. Ministry of Environment and Tourism and Namibia Nature Foundation, Windhoek.

Simoneau, E. L. 1974. Les animaux du Territoire Francais des Afar at des Issas. E.-L. Simoneau, Djibouti.

Smallie, J. \& Virani, M.Z. 2010. A preliminary assessment of the potential risks from electrical infrastructure to large birds in Kenya. Scopus 30: 32-39.

Smallie, J., Diamond, M. \& Jenkins, A. 2009. Lighting up the African continent - what does it mean for our birds? In: Harebottle, D.M., Craig, A.J.F.K., Anderson, M.D., Rakotomanana, H. \& Muchai, M. (Eds). Proceedings of the 12th Pan-African Ornithological Congress, 2008, Cape Town, pp. 38-43. Animal Demography Unit.

Smith, K.D. 1957. An annotated check list of the birds of Eritrea. Ibis 99: 1-26, 307-337.

Snow, P.W. (Ed.) 1978. An atlas of speciation in African non-passerine birds. British Museum of Natural History, London.

Stumpf, W. 2002. Egyptian Vulture at Pilansberg, South Africa. Vulture News 46: 39-40.

Tauler-Ametller, H., Hernández-Matías, A., Pretus, J.L. \& Real, J. 2017. Landfills determine the distribution of an expanding breeding population of the endangered Egyptian vulture Neophron percnopterus. Ibis 159: 757-768.

Taylor, M., Peacock, F. \& Wanless, R.M. (Eds) 2015. Eskom Red Data Book of Birds of South Africa, Lesotho and Swaziland. BirdLife South Africa, University of Cape Town and South African National Biodiversity Institute. Johannesburg, South Africa.

Taylor, P.B. 1982. E.A.N.H.S. nest record scheme: 1982. Scopus 6: 129-143.

Thévenot, M., Bergier, P. \& Beaubrun, P. 1985. Present distribution and status of raptors in Morocco. In: Newton, I., Chancellor, R.D. (Eds). Conservation studies on raptors, pp. 83-101. ICBP Technical Publications No. 5. International Council for Bird Preservation, Cambridge.

Thévenot, M., Vernon, R. \& Bergier, P. 2003. The birds of Morocco. BOU Checklist No. 20. BOU, Tring.

Thiollay, J.M. \& Dupuy, A.R. 1970. Les rapaces du Parc National du Niokolo Koba. Données préliminaires. L'Oiseau et la Revue Française d'Ornithologie 40: 115-130.

Thiollay, J.-M. \& Mostefai, N. 2004. Le peuplement ornithologique de l'Ouest Algérien: observations inédites en période de nidification. Alauda 72: 335-337. 
Thiollay, J.M. 1975. Les rapaces des Parcs Nationaux du Tchad meridional. L'Oiseau et la Revue Française d'Ornithologie 45: 27-40.

Thiollay, J.M. 1977. Distribution saisonnière des rapaces diurnes en Afrique occidentale. L'Oiseau et la Revue Française d'Ornithologie 47: 253-294.

Thiollay, J.-M. 1989. Distribution and ecology of Palaearctic birds of prey wintering in West and Central Africa. In: Meyburg, B.-U. \& Chancellor, R.D. (Eds). Raptors in the modern world, pp. 95-107. World Working Group on Birds of Prey, Berlin.

Thiollay, J.-M. 2006. Severe decline of large birds in the northern Sahel of West Africa: a long-term assessment. Bird Conservation International 16: 353-365.

Thiollay, J.-M. 2007. Raptor population decline in West Africa. Ostrich 78: 404-413.

Thomsett, S. 1987. Raptor deaths as a result of poisoning quelea in Kenya. Gabar 2: 33-38.

Thouless, C.R., Fanshawe, J.H. \& Bertram, B.C.R. 1987. Egyptian Vulture Neophron percnopterus and Ostrich Struthio camelus eggs: the origins of stone-throwing behaviour. Ibis 131: 9-15.

Toschi, A. 1969. Avifauna Italiana. Editoriale Olympia, Florence.

Trotter, W.D.C. 1970. Observations faunistiques sur I'lle de Lanzarote (Canaries). L'Oiseau et R.F.O. 40(2): 160-172.

Tucker, G. 2005. Status report on raptors in the African-Eurasian region: review of the status of migratory raptors in Africa and Eurasia. Department for Environment, Food and Rural Affairs (DEFRA). London, $79 \mathrm{p}$.

Turner, D.A. \& Pearson D.J. (Eds) 1991. Species report [East African bird report 1989]. Scopus 13: 138164.

Tyler, S.J. 1978. Some observations of birds in Fah, northeast Eritrea. Bulletin of the British Ornithologists' Club 98: 80-87.

Valverde, J. A. 1957. Aves del Sahara Español: Estudio ecològico del desierto. Instituto de Estudios Africanos, Madrid.

van Lawick-Goodall, J. \& van Lawick-Goodall, H. 1966. Use of tools by the Egyptian Vulture, Neophron percnopterus. Nature 212: 1468-1469.

van Someren, V.G.L. 1956. Days with birds. Fieldiana: Zoology 38.

Verdoorn, G.H. 2004. Vultures in the Northwest Province of South Africa. In: Monadjem, A., Anderson, M.D., Piper, S.E. \& Boshoff, A.F. (Eds). The vultures of Africa - Quo Vadis? Proceedings of a workshop on vulture research and conservation in southern Africa, pp. 100-105. Birds of Prey Working Group, Johannesburg, South Africa.

Vernon, C.J. \& Boshoff, A.F. 1997. A review of the status of the vultures in Eastern Cape Province, South Africa. In: Boshoff A.F., Anderson, M. \& Borello, W. (Eds). Vultures in the $21^{\text {st }}$ Century: proceedings 
of Workshop on Vulture Research and Conservation in Southern Africa, pp. 67-75. Vulture Study Group, Johannesburg.

Vernon, C.J. 2004. The Eastern Cape's Vultures. In: Monadjem, A., Anderson, M.D., Piper, S.E. \& Boshoff, A.F. (Eds). The vultures of Africa - Quo Vadis? Proceedings of a workshop on vulture research and conservation in southern Africa, pp. 78-80. Birds of Prey Working Group, Johannesburg, South Africa.

Virani, M.Z., Kendall, C., Njoroge, P. \& Thomsett, S. 2011. Major declines in the abundance of vultures and other scavenging raptors in and around the Masai Mara ecosystem, Kenya. Biological Conservation 144: 746-752.

Volsoe, H. 1951. The breeding birds of the Canary Islands. Introduction and synopsis of the species. Vidensk. Meddr dansk. naturh. Foren 113: 1-153.

Wacher, T., De Smet, K., Belbachir, F., Belbachir-Bazi, A., Fellous, A., Belghoul, M. \& Marker, L. 2005. Sahelo-Saharan Interest Group Wildlife Surveys. Central Ahaggar Mountains (March 2005). iv + 34 pp.

Wacher, T., Newby, J., Houdou, I., Harouna, A. \& Rabeil, T. 2013. Vulture observations in the Sahelian zones of Chad and Niger. Bulletin of the African Bird Club 20(2): 186-199.

Walsh, J.F. 1987. Records of birds seen in north-eastern Guinea in 1984-1985. Malimbus 9: 105-122.

Watson, R.T. 1986. The biology, ecology and population dynamics of the Bateleur Eagle (Terathopius ecaudatus). PhD Thesis, Univ. Witwatersrand.

Watson, R.T., Fuller, M., Pokras, M \& Hunt, G. (Eds) 2009. Ingestion of Lead from Spent AmunitionImplications for Wildlife and Humans. The Peregrine Fund. Boise.

Welch, G. \& Welch H. 1991. Spring raptor observations from Djibouti. Ornithological Society of the Middle East Bulletin 26: 25-27.

Welch, G.R. \& Welch, H.J. 1984. Djibouti expedition March 1984, pp. 60.

Welch, G.R., Welch, H.J. \& Rayaleh, H.A. 2009. Djibouti Francolin survey March 2009. Unpublished report pp. 26.

Whitaker, J. I. S. 1905. The birds of Tunisia: being a history of the birds found in the regency of Tunis. R. H. Porter, London.

White, M., Mohammed, A., Dauphine, N., Gilbert, F., Zalat S. \& Gilbert, H. 2008. Recent survey of resident breeding birds in the St Katherine Protectorate, South Sinai, Egypt. Sandgouse 30: 190-200.

Wilhelmi, F.K. \& Kaariye, H.Y. 2006. Bird observation in the Ogaden Region, Somali Regional State/Ethiopia. A contribution to the identification of Important Bird Areas. Project report.

Wilson, R.T. 1982. Environmental changes in western Darfur, Sudan, over a half century and their effects on selected bird species. Malimbus 4:15-26. 
Yosef, R. \& Alon, D. 1997. Do immature Palearctic Egyptian Vultures Neophron percnopterus remain in Africa during the northern summer? Vogelwelt 118: 285-289.

Zimmerman, D.A., Turner, D.A. \& Pearson, D.J. 1996. Birds of Kenya and northern Tanzania. Christopher Helm, London.

Zinner, D., Pelaez F., Torkler F. \& Berhane D. 2001. Primates of Eritrea: current distribution and habitat. African Primates 5: 7-17.

$* * * * * *$ 